Running head: WHAT IS AN "ETHNIC GROUP" IN ORDINARY PEOPLE'S EYES?

\title{
What is an "ethnic group" in ordinary people's eyes? Different ways of understanding it among American, British, Mexican, and Polish respondents
}

\begin{abstract}
While the term "ethnic group" (EG) is often used in social studies, its definition differs among researchers. Moreover, little is known about ordinary people's subjective understanding of this term, even though it is often used in social discourse. We examined this issue in a cross-sectional study of 273 American, British, Mexican and Polish students using an open-ended questions approach. Results revealed cultural differences in patterns of "ethnic group" definitions across the four countries. U.S. respondents predominantly connected EG to "race"; British participants frequently related it to "race," but more often to "common culture" and "customs/traditions." Both latter categories were overwhelmingly dominant in Mexico and Poland. However, "nation," "shared history," "religion," "language" and "territory" were also very popular as EG understandings in Poland. While most participants used the newer definition of EG (referring to all groups in a society, including minority and majority groups), a few in each country used the term only to refer to minorities and people different from themselves (an older, "minus one" definition). Unexpected definitions of EG also appeared (e.g., people having similar hobbies, work goals or living in the same city). The results also indicate that for the US, UK and Mexico, "ethnic group" was more a subgroup within a nation, while in Poland they represented the same level of categorization. The theoretical and practical implications of our findings are discussed.
\end{abstract}




\section{Introduction}

The terms "ethnic group" (EG) or "ethnicity" have been studied by a range of disciplines including statistics, demography, political science, sociology, history, ethnology, and anthropology, as well as geography and psychology. A quick look into the Academic Databases EBSCO shows over 57,000 hits for EG in the PsycInfo database alone, with another 36,000 for "ethnicity." However, there is no agreement on their definitions across or even within disciplines, as researchers differ in perceiving their content and scope (see e.g., Banton, 2007; Barth, 1969; Bhopal \& Donaldson,1998; Gil-White, 2005; Phinney, 1996; Phinney, Horenczyk, Liebkind \& Vedder, 2001). Some researchers simply avoid defining the term-Isajiw's (1974) meta-analysis of 65 sociological and anthropological studies dealing with ethnicity showed that only 13 of them included a definition. Their reason may be what Omi and Winant (1994, p.14) summarized as "The definition of the terms 'ethnic group' and 'ethnicity' is muddy." Further, the meaning of "ethnic group" has changed and is changing constantly (Zelinsky, 2001).

There is also much confusion in the way people across countries and cultures use the terms (Shiraev \& Levy, 2004). Some researchers use the word "ethnicity" interchangeably with "race" (e.g., in the US), some with "nation" (e.g., in Eastern Europe; also see Peterson Soendergaard \& Kara, 2017; Vermeulen, 2015; Zelinsky, 2001), and others with "culture" (see e.g. Benet-Martinez \& Hong, 2014; Benet-Martinez \& Oishi, 2008; Bobowik, Martinovic, Basabe, Barsties \& Wachter, 2017; Brubaker, Loveman \& Stamatov, 2004; Deaux \& Verkuyten, 2011; Fouad \& Byars-Winston, 2005; Gil-White, 2005; Phinney, 1996; Shiraev \& Levy, 2004; Smedley \& Smedley, 2005; Vermeulen \& Govers, 1994). Moreover, human groups are constantly moving and mixing and, as a result, people have some freedom to choose their cultural and ethnic identity and the group with which they want to identify. Thus, such phenomena as ethnic or national identity are becoming increasingly dynamic and based on the differing interests, ideas and choices of individuals (Burton, Greenberger \& Hayward, 2005; Shiraev \& Levy, 2004).

If there is so much ambiguity in defining "ethnic group" among scholars, it seems important to examine how ordinary people define the term. This knowledge is crucial, for example, in conducting research. In psychological or sociological studies participants' characteristics are often used and one of these characteristics is self-ascribed ethnicity or ethnic 
group. When asked to identify their ethnic group, how do respondents understand this term? And is that understanding constant across cultures, or does it vary from culture to culture? Answering such questions is vital for the interpretation and application of the results of studies of ethnicity, including large scale international surveys, such as the World Values Survey or the European Values Survey (EVS, n.d.; World Values Survey, n.d.). Before results of such cross-national surveys can be compared, researchers must understand the meanings that members of the surveyed cultures assign to these concepts. Conceptualizations and operationalizations of such concepts should take into account the differences in how this term is understood by individuals from different countries.

Additionally, the term "ethnic group" is often used in media and public debates on important social issues (for examples from the UK, US, Poland and Mexico see e.g. Duncan \& Edwards, 2017; Jedlecki, 2016; Klimas, 2018; Milenio, 2017; Slawson, 2017; Weinstein, 2018 etc.). Meanwhile little research exists on how individuals understand the term. The starting point to understanding the meaning of concepts, including "ethnic group," is to realize that these concepts, as both social practice and ideology, manifest themselves discursively (Wodak \& Reisigl, 2003). Exploring it is of great importance, because people's understanding of the social world has an impact on attitudes and behaviors in social, political, and economic dimensions (Inglehart \& Welzel, 2005). The popular understanding of the term "ethnic group" is no exception, particularly because attitudes towards minority ethnic groups have been shown to influence social cohesion, attitudes towards public policy initiatives, and support for specific political parties (e.g. Dustmann \& Preston, 2001; Verkuyten, 2018).

The research reported in this article addresses the question on how ordinary people understand the term "ethnic group." We expect the EG definitions to depend on socio-cultural context; hence, this research is conducted in four different countries on two continents, each possessing a different socio-cultural context, ethnic makeup, and history. In a cross-sectional study, U.S., U.K., Mexican, and Polish participants were asked to describe their understandings of the term "ethnic group." Their answers were analyzed both quantitatively and qualitatively.

\section{Various definitions of the term "ethnic group"}

The term "ethnic" was derived from the word ethnos (Greek: people or nation) and during the $18^{\text {th }}$ century became the object of research in ethnology, which is now called cultural anthropology in the US and social anthropology in the UK (Vermeulen, 2015). The word 
Running head: WHAT IS AN "ETHNIC GROUP" IN ORDINARY PEOPLE'S EYES?

"ethnic" was used by Homer to describe a swarm or flock of animals, "a biologically defined grouping" (Schaefer, 2008, p. 456). Later, it was applied to humans to mean a unity of persons of common culture and language or of common blood and descent. At some point "ethnic" also indicated pagans, and by the $20^{\text {th }}$ century it was used to refer to "others," those who were not "us" (Purkayastha, 2008; Schaefer, 2008).

The latter way of defining EG as "otherness" and "minority" can be still found in some scholars' work (e.g. Phinney, 1996) and in contemporary dictionaries, which are a common source of knowledge for laypeople or media. For example, Oxford Dictionaries define EG as "Relating to a population subgroup (within a larger or dominant national or cultural group) with a common national or cultural tradition: 1.1 Relating to national and cultural origins; 1.2 Denoting origin by birth or descent rather than by present nationality < ethnic Indian populations >; 1.3 Characteristic of or belonging to a non-Western cultural tradition" (Ethnic, n.d.-b). This has been called "minus one" ethnicity as members of the dominant group omit their own when adding up the number of ethnic groups (Banton, 1998). Thus, ethnic identity might refer to identification with a group that is perceived as being different from the majority, whether for cultural, "racial," or religious reasons (Persky \& Birman, 2005; see also Merino \& Tileagă, 2011; Verkuyten \& de Wolf, 2002a, 2002b). At some point, the historical meaning of "ethnic," which meant "different from the majority" or the "outsider," shifted from implying religious differences to cultural ones (Persky \& Birman, 2005). For example, Aboud and Skerry (1984) use the term "ethnic group" to refer to a socially and/or psychologically defined set of people who share a common culture or cultural background, often because of similarity of "race," nationality or religion. Ross argues that "ethnic groups are social and political, but also cultural, groupings" (Ross, 1997, p. 300). Interestingly, "ethnic" in this context often means identification with the culture of origin, not with a new culture or society, which may be multi-ethnic (Phinney et al., 2001).

However, from 1975 on, the term ethnicity started to be used when referring to all groups in a society "characterized by a distinct sense of difference because of culture and descent" (Purkayastha, 2008, p. 456), including majority groups. This way of defining EG also can be found in contemporary dictionaries (see e.g. Ethnic, n.d.-a). Through this evolution, the meaning of ethnicity came closer to the European concept of nationality (Schaefer, 2008). 
The "nonminority" approach to an understanding of "ethnic group" was strongly endorsed in the $19^{\text {th }}$ century by Max Weber, who focused on the subjective belief of group members that they have common descent, perceived ancestry, culture, and language. "Subjective belief in common descent can be based on a similarity of physical type and custom, but which cultural components are important varies from group to group" (Purkayastha, 2008, p. 457). Adding physical features to the definition of ethnic group made it closer to the term "race," which for Weber belonged to one category with ethnicity (Banton, 2007; Purkayastha, 2008).

Ethnic groups are therefore subject to change and redefinition, as the result of a social process in which people draw boundaries around themselves, producing and reproducing culture, acknowledging ancestry, and using their language as an emblem of the group (Purkayastha, 2008). Also, according to Barth (1969), ethnic groups are not fixed; instead, they are open, flexible and often self-defined. This approach suggests that ethnicity is transmissible to other people because culture traits are learned (Smedley \& Smedley, 2005).

Analyzing definitions of ethnicity in 65 sociological and anthropological studies, Isajiw (1974) identified ten of its most common attributes, as follows (from the most common): common geographical or national roots or common ancestry; common culture, practices, religion, physical or racial; language; we-consciousness; loyalty and community; social bond domination; common values; separate institutions; minority status; immigration genesis.

More recently, Zelinsky (2001) examined the many ways that EG has been defined: as minority or political status, attachment to a location, sharing a common language, religion, or place of origin. He found all inadequate, as for him EG is simply a social construction that arises in many historical circumstances and evolves constantly. Instead, he offers a "stripped-down" definition as follows, "The ethnic group is any substantial aggregation of persons who are perceived by themselves and/or others to share a unique set of cultural and historical commonalities" (Zelinsky, 2001, p. 43).

\section{"Ethnic group" and cultural context}

The history of the distinctions between the terms "ethnicity," "race," nations and ethnic groups is highly complicated (Vermeulen, 2015). From American researchers' perspective, especially in psychology and sociology, ethnicity is very much connected to "race," with the two concepts strongly overlapping (Phinney \& Ong, 2007). For example, Huynh, Devos and Altman (2015), who examined the prototypicality of different ethnic groups for American identity, took 
into consideration European American, Asian American, Latino/as and African American ethnic groups. Similar confusion appears in the UK, where "race is generally classified in U.K. policy documents as equivalent to ethnicity" (Evans, 2010, p. 119). However, Benet-Martinez (2008; Benet-Martinez \& Oishi, 2008) calls using the terms "ethnicity" and "race" interchangeably a common mistake, as "ethnicity" usually implies a shared identity and cultural ancestry while "race" does not (see also Schaefer, 2008). Similar problems concern confusing "ethnicity" and "culture", as "culture" is viewed as a broader concept (Benet-Martinez, 2008; Minkov \& Hofstede, 2011).

Additionally, there are many problems and misunderstandings about the term "race," starting from doubts about its biological reality (see e.g. Banton, 1998, 2015; López Beltrán, 2000; Smedley \& Smedley, 2005). A theory of permanent racial types is called "the most serious source of misunderstanding" and "an error in the science of pre-Darwinian era" (Banton, 1998, p. 3), while "race" is seen as "a pseudo-scientific concept" (Quraishi \& Philburn, 2015, p. 122). From the perspective of genetics, the assumption of different human "races" is incorrect, as it implies the existence of "pure races." Since all human populations have diverse genetic origins, this notion has been known for over a century to lack scientific justification (Banton, 1998). As Fenton adds, "the degree of variation within postulated races came to be recognized as greater than the variation between them" (Fenton, 1999, p. 5). Moreover, the term "race" can be understood in many different ways - as a lineage, subspecies, class, status or social construct (Banton, 1998; Wodak \& Reisigl, 2003). Because of such confusions, and their consequences during World War II, the UNESCO committee on "race" suggested to replace this term with “ethnic group" (UNESCO, 1952), coined by Deniker (1900). As Ashley Montagu, who chaired the committee, pointed out, national, religious, linguistic, geographic, and cultural groups do not coincide with "racial group." (as cited in Vermeulen, 2015; see also UNESCO, 1952).

Thus, many researchers argue that ethnicity refers to people who, apart from "race," also share origins or social background, a common language, a specific geographic location, religious tradition and identity, and a set of traditions and customs that distinguish their ethnic group from others in their "racial" group, including style of speech and/or style of dress (e.g. Benet-Martinez \& Hong, 2014; Senior \& Bhopal, 1994).

The editors of the Harvard Encyclopedia of American Ethnic Groups, Thernstrom, Orlov and Handlin (1980), recognizing that ethnicity is an immensely complex concept, decided to 
treat as "ethnic groups" any aggregate characterized by some of the fourteen following features, although in combinations that vary considerably (Smith, 1982): common geographic origins; migratory status; race; language or dialect; religious faith or faiths; ties that transcend kinship, neighborhood, and community boundaries; shared traditions, values, symbols; literature, folklore and music; food preferences; settlement and employment patterns; special interests in regard to politics in the homeland and in the US; institutions that specifically serve and maintain the group; an internal sense of distinctiveness; and an external perception of distinctiveness.

Their approach demonstrates the categories valid for understanding ethnicity in the US, but would they be valid for other countries and cultures as well? Not necessarily, as an example with the term "nation" shows. According to Purkayastha (2008), the evolution of the meaning of EG made the term closer to the European concept of "nationality," present especially in some Central and Eastern European countries such as Poland. In the US the term "ethnicity" usually indicates cultural heritage, the experience shared by people who have a common ancestral origin, language, traditions, and often religious and geographic territory, and is used to refer to subgroups within a larger national context (e.g., Phinney et al., 2001). However, "nation" is defined similarly - as people who share common geographical origin, history, and language, with a significant addition-unification as a political entity. Thus, it seems that for some cultures, "ethnic group" is more a subgroup within "nation" (being a larger context for them), while in others, "EG" and "nation" are more closely tied, representing a similar, or even the same, level of categorization.

Moreover, according to Weber there are no universal cultural traits characterizing ethnic groups, as many traits can play the role of differentiating one group from others: language, religion, hairdo, clothes, food and eating habits, division of labor between group members, etc. (Purkayastha, 2008). Thus, there cannot be a universal definition of "ethnic group" except the idea of common descent and some cultural or physical markers (Purkayastha, 2008).

Finally, the census' or surveys' format of closed-ended questions brings additional problems. "Methodological studies of census questions about "race" and ethnicity, for instance, show that responses are affected, often remarkably so, by the format of questions, the listed choices, and the examples included in questionnaire instructions" (Perez \& Hirschman, 2009, p. 3). In social studies asking about belonging to an "ethnic group" usually means giving participants a set of choices, triggering only one way of understanding the term in their minds, 
without examining how they understand it. The present study seeks to explore the issue of lay definitions of "ethnic group," a topic the examination of which is of growing importance.

\section{Present study}

To date, no research has explored which categories play a crucial role in ordinary people's understanding of the term "ethnic group," especially in different cultures. What are the main patterns they use to define EG in different cultural contexts? The present cross-sectional study fills this gap by exploring: (1) understandings of an "ethnic group" reported by U.S., U.K., Mexican, and Polish samples of non-specialists; (2) differences in patterns of understanding of this term in the countries studied, connected to their ethno-cultural context.

Due to the exploratory nature of the study and the qualitative typology of the answers, we did not formulate specific hypotheses, but developed some guiding expectations based on the ethnic makeup, national history, geographic location, religious and socio-cultural characteristics of the four countries.

The selection of countries for the study (Mexico, the United States, the United Kingdom and Poland) was based on their differences in the mentioned areas and the various roles they play in the global migration movements: the US and the UK receive the most immigrants, and they often originate in Poland and/or Mexico (Hallett, 2016).

These four countries also differ on many dimensions of cultural comparisons. For example, on the two dimensions of the Inglehart-Welzel Cultural Map, Poland and Mexico are more on the traditional side of the "traditional" versus "secular rational" values dimensions than are the US and the UK, which means a higher importance of religion, higher levels of national pride and a more nationalistic outlook for Poles and Mexicans than for U.S. and British citizens. Poland is also more on the "survival" side of the survival vs. self-expression dimension than the remaining three countries, which means more emphasis on economic and physical security and a relatively ethnocentric outlook (World Values Survey, 2015).

The Inglehart-Welzel approach was expanded by Haller (2002), introducing the "deeper level-analysis" for both dimensions, which also differentiates the four countries analyzed in this article. His analysis of the "survival" vs. "self-expression" dimension resulted in the concept of "nationhood"- the process of nation-building and the security and pride of national identity. Moreover, following the "traditional versus secular-rational values" dimension, Haller (2002) differentiated general types of relations between religions/churches and states. 
The characteristics of the four countries tested, which may be necessary for understanding the potential differences in "ethnic group" definitions are summarized below. - The United Kingdom, a sovereign state in Western Europe consisting of four countries: England, Scotland, Wales and Northern Ireland; a part of the European Union (the present research was conducted half a year before the Brexit vote):

In Haller's analysis, the UK is described as a typical example of a "state nation" in which the state created the nation by introducing comprehensive education and language, national symbols, and so forth, as a deliberate political strategy. Anyone may become a member of such a "state nation" if they are willing to learn its language and respect its laws and institutions (Haller, 2002). The UK is also an example of a country where the comprehensive state renders superfluous or replaces religious communities with a historical "state religion"; today, it is a quite well-developed welfare state, reporting a decline in religiosity. According to the 2011 census (ONS, 2013), in England and Wales, 25\% reported not being religious, 59\% were Christians and 5\% Muslims. In Scotland's census (2011b), 32\% declared membership in the Church of Scotland, $16 \%$ were Roman Catholics, other Catholics - 6\%, Muslim - 1\%, other religions $-1 \%$, not stated $-7 \%$ and not religious $-37 \%$.

As for ethnic/"racial" groups officially recognized in the UK, the Office for National Statistics (ONS, 2011) combines "race" and nationality as an ethnic group classification scheme. In the U.K. censuses, the majority of the resident population, 86\% in England and Wales (a drop from 94\% in 1991) and 96\% in Scotland, indicated their ethnic group as "White" (ONS, 2012; Scotland's Census, 2011a). Within this ethnic group, in England and Wales White British was the largest $(81 \%)$, followed by Any Other White (4.4\%), Indian (2.5\%) and Pakistani (2\%). In Scotland's Census (2011a) 84\% were White Scottish residents, $8 \%$ White-Other British, $1 \%$ White-Irish, 1\% White-Polish, 2\% White-Other (including Gypsy/Traveler), 3\% of Asian-Asian Scottish and 1\% of Other Ethnic Groups. The population is more diverse in some areas, especially in big cities. London was found to be the most ethnically diverse (also with a much lower proportion of English as a dominant language), while Wales was the least diverse.

English is the official and most frequently spoken language in the UK. In the $2011,92 \%$ of people in England and Wales reported English as their main language (English or Welsh in Wales). The remaining $8 \%$ of the population had a main language other than English, including Polish, Penjabi, Urdu, Bengali and others (ONS, 2011). 
High immigration has influenced the British population. Migration Statistics Quarterly Report notes that immigration was estimated to be 268,000 EU citizens and 257,000 non-EU citizens in 2016 (ONS, 2017). These data allow us to suspect that, with high immigration rates, cultural factors, including religion and language, often different from traditional ones in the country, may be categories of rising importance in the social perception of the meaning of "ethnic group" in the UK. Additionally, the fact that four countries in the UK occupy different territories and have separate censuses (as well as separate national assemblies, sports teams, etc.) suggests that British nationals may have a quite fine-grained identity. Thus, geographical and national references may be another important category among EG definitions in the UK.

- Poland, a country in Central/Eastern Europe, a part of the European Union:

Poland is considered a nationally and religiously homogeneous state, as the index of ethnic cohesion (over 97\%) sets it on one of the first places in Europe, and even in the world at large (Rykala, 2014). As a "monoracial" country (almost only "White", as "race" is often understood in Poland as a skin color), Poland does not have official data on "racial" groupingsin the Statistical Yearbook of The Republic Of Poland the word "race" is never used (Central Statistical Office, 2015). The Polish Ministry of Internal Affairs distinguishes nine national minorities (Belarusians, Czechs, Lithuanians, Germans, Ormians, Russians, Slovaks, Ukrainians, Jews), four ethnic minorities (Karaim, Lemko, Romani, Tatar) and one language minority (Kashubian; MSWIA, n.d.). However, according to the National Census from 2011, none of these exceeded $0.5 \%$ of the Polish population.

Polish is the official language in Poland, although in some communities auxiliary official languages are allowed (German, Belarusian, Lithuanian and Kashubian). As the National Census from 2002 showed, the Polish language was used at home by a group of people larger (97.8\% of the overall population) than the group declaring Polish nationality (96,7\%; Rykala, 2014). This was the first census after WWII to provide statistical data on the national identification of Poles.

In Haller's analysis (2002), Poland would be an example of an "ethno-nation." In its history, the fight for national heritage, unity and independence plays an important part. During the $18^{\text {th }}$ century, Poland lost its independence for 123 years (until 1918), being occupied by Russia, Germany, and the Austro-Hungarian Empire. With restored independence for the period between the two world wars, after WWII Poland fell under Soviet occupation until 1989. The need to preserve the identity of the nation during times of lost independence pushed Poles to 
fight for their language, culture, and history (e.g., organizing secret lessons for Polish children in order to cultivate Polish heritage). In addition to language and culture, the ethnic factor, that is, the (believed) community through common ancestry, plays an important role (Haller, 2002). Moreover, religion has been an important factor in the formation of many nations and the maintenance of national consciousness (Rykala, 2014), and this is definitely the case in Poland. The Catholic Church has historically been the institution which for centuries strongly preserved the idea of the Polish nation against dominant foreign nations, also in the time of lost independence. Therefore, until today, the church has played a complementary role to the state. According to the National Census from 2015, 92.4\% of Poles consider themselves Catholic, and only $1.4 \%$ of Poles are members of other religions (Central Statistical Office, 2015).

On the basis of these considerations, we expected Poles to strongly refer to EG as connected to the nation, territory, common ancestry, religion, history, and language.

- The United States of America, a country in North America:

In Haller's (2002) analysis, the US, like the UK, is described as an example of a "state nation." However, the US is an example of the second type of religion-state relationship, a "complementary relationship," where church membership and religious participation fulfill specific, important social functions not carried out by the state. With a wide variety of ethnic groups and immigrants from around the world, membership in a religious denomination has always been an important element of social and cultural integration in the US, with churches serving a significant role in social life (Haller, 2002). Moreover, some anti-Muslim sentiments which appeared after the 9/11 terrorists attacks and growing anxiety about Islam's (especially Islamic fundamentalism's) compatibility with Western value of tolerance (Panagopoulos, 2006) may also be a basis for thinking that religion could be an important reference point in defining EG in the US. However, religious liberty being a core value, expressed in the First Amendment to the U.S. Constitution, could suggest otherwise. Statistics show that $71 \%$ of Americans selfidentify as Christian (25\% Evangelical Protestant, 21\% Catholic,15\% Mainline Protestant, 6\% Black Protestant, 1.6\% Mormon), 2\% as Jewish, 1\% as Muslim, 3\% as other faiths (with Buddhist and Hindu both below 1\%), and 23\% "none/unaffiliated," including 4\% agnostic and 3\% atheist (Pew Research Centre, n.d.).

The US boasts remarkable ethnic and "racial" diversity (Huynh et al., 2015). As for "racial" categories, the U.S. Bureau of the Census has changed them over the years (Phinney, 
Running head: WHAT IS AN "ETHNIC GROUP" IN ORDINARY PEOPLE'S EYES?

1996). Moreover, the boundaries between "racial" and ethnic groups are becoming blurred by high rates of intermarriage and the growing number of persons with mixed ancestry (Lee \& Bean, 2004; Perez \& Hirschman, 2009). However, "race" is still an important category in U.S. society and is expected to appear in EG definitions in our study. In 2016 "racial" categories in the US were: White (comprising about $77 \%$ of the U.S. population); Hispanic (17.8\%); Black or African-American (13.3\%); Asian-American (5.7\%); multi-racial (2.6\%); American Indian/Alaskan Native (1.3\%) and Native Hawaiian/Pacific Islander (0.2\%; U.S. Census Bureau, 2016).

The US is a country built and developed by immigrants. They came from all over the world, bringing their own culture, beliefs, religion, history, and values (see e.g., Gilder Lehrman Institute, n.d.). As a result of its highly mixed-origin society, it is common to have multiple countries of origin in one's family tree. Hence, we did not expect references to the place of origin or ancestors to be very popular as an EG definition. Instead, "race" (as dominant), culture and traditions might play the key roles.

- Mexico, a country in North America, part of Latin America:

There is great cultural and ethnic diversity in Mexico. According to the Mexican Ministry of Culture, it contains 68 different indigenous ethnic groups (Milenio, 2017), with striking genetic diversity caused mostly by territorial isolation from one another (Moreno-Estrada et al., 2014). Mexico's population is composed of indigenous American Indians (Amerindians, 20\%), Mexicans of European heritage ("Whites," 20\%) and those with a mixture of indigenous and European heritage_-"mestizos" (50-60\%) — "via a complex blending of ethnic traditions and perceived ancestry" (Mexico. Ethnic groups, n.d.). Racial identity remains a powerful social construct in Mexico, exemplified by the special celebration day of heritage and "race" on October 12, the Día de la Raza ("Race Day")—whether people conceive of themselves as indigenous, mestizo, or European. The identities of Mexicans as members of ethnic groups may be additionally complicated, given that "ethnicity is a function of cultural patterns and traditions as varied as a group's sense of linguistic, religious, and socioeconomic history" (Mexico. Ethnic groups, n.d.).

According to the Encyclopadia Britannica, "specific cultural areas have evolved in Mexico because of differences in physical environment, ethnicity, and settlement histories, and few of the regions correspond exactly with the country's physiographic regions. Mexico 
Running head: WHAT IS AN "ETHNIC GROUP" IN ORDINARY PEOPLE'S EYES?

traditionally has been divided between the Spanish-mestizo north and the Indian-mestizo south, corresponding roughly to the pre-Columbian boundary that separated the highly developed indigenous civilizations of the Mesa Central and the south from the less agriculturally dependent groups to the north. The country can be further divided into ten traditional cultural regions" (Mexico, n.d.).

However, the Mexican government has defined ethnicity as based on cultural standards rather than on "racial" ones. Between 1921 and 2015, it did not ask for the ethnicity nor the "race" of its citizens. The number of indigenous people was defined narrowly based on the number of speakers of one Mexico's many indigenous languages or connections to established indigenous communities. According to the Mexican census conducted by Instituto Nacional de Estadística y Geografía (INEGI, 2010a), 24.4 million people identify themselves as indigenous (21.5\% of the Mexican population) and/or Afro-Mexican (1.2\% of the population; Both can be indicated simultaneously). No other groups (e.g., mestizos, "Whites" or Asian-descendants) are quantified by the government. However, the available estimates may be imprecise, as it is common for indigenous people, for various reasons, to deny their ethnic status (Sandoval Forero, 2002).

Mexico has 7 million citizens (7\%) who speak indigenous languages. The National Institute of Indigenous Languages (INALI, 2008) recognized 68 linguistic groups and 364 varieties of indigenous languages. There are 494 municipalities where more than $40 \%$ of inhabitants speak indigenous languages. Specific languages are often spoken in specific geographical areas, for example, Maya speakers constitute the majority in the rural Yucatán and the Chiapas Highlands, while Huasteco is spoken mostly in northern Veracruz (Mexico. Ethnic groups, n.d.).

Scholars in Mexico criticize national censuses for using the criterion of a linguistic and not of a socio-anthropological nature. However, they admit that until now it is the only cultural and social characteristic that has been possible to register as a statistical variable in censuses and population counts. For this reason, the question "who is an indigenous" from a socioanthropological perspective remains open (Sandoval Forero, 2002). Our study offers a first small step towards unravelling this mystery.

As for national minorities, in 2015, the foreign-born population was over 1 million (INEGI, 2016), the majority of whom were born in the US. The next largest immigrant groups 
are Guatemalans, Spaniards, and Colombians. Besides the Spanish, large immigrant-descended groups are the French, Germans, Lebanese, and Chinese.

As for religions, according to INEGI (2010b), $83 \%$ of Mexicans are Catholics, but there are also Protestants (8\%), Jehovah's Witnesses (1.4\%), members of other religions (below 1\%) and around $8 \%$ atheists and indefinites. Haller (2002) describes Mexico as a country of high religiosity where religious communities are partial substitutes for a weak state. This fact suggests a possible important role of religion in defining ethnic groups. However, on the basis of the above considerations, it seems that in Mexico there are even more important categories for defining EG such as culture, language, "race," and genes or "physical features," as well as geographical references.

\section{Research questions}

To sum up, on the basis of the above considerations, we expected various categories to be used by ordinary people from the countries tested to define "ethnic group." Those used by official statistics in their countries and historical context should partially shape individuals' definitions. However, other categories from popular dictionaries and other sources may also be salient in people's minds, due perhaps to education, social discourses, media influence, immigration patterns, and other cultural factors.

In summary, given these cultural variations, we expected different patterns in characterizing "ethnic group" by ordinary individuals in four studied countries. Among the most popular definitions of the term we expected the following:

- In Poland: nationality, geographical references, culture, including language and religion, common history and ancestry;

- In Mexico: culture, including language and religion, geographical references, "race", genes, and physical features;

- In the US: "race" and culture, including religion;

- In the UK: "race", geographical references and culture, including religion and language.

We also wanted to check which perspective in defining "ethnic group" will be dominant: referring to all groups in a society, or the classic, old "minus one" definition (Banton, 1998). Finally, we expected that for the US, the UK and Mexico "ethnic group" would be more a subgroup within a nation, while in Poland, "ethnic group" and nation will be more closely tied, representing a similar, or even the same, level of categorization. 


\section{Method}

Procedure: Participants completed an online survey in their native language (English, Polish or Spanish, respectively). The questionnaire was prepared originally in Polish and then backtranslated to the respective languages of the studied countries (Brislin, 1970).

Measures: Ethnic group understanding was explored by the open-ended question: "How do you understand the concept of an ethnic group? Give us your first thoughts and associations. Specify what kind of a group this is in your case." After the open-ended questions had been answered and that section closed so that participants could not return to it, we also asked for sociodemographic information (gender, age, place of residence, religion). As a last question, in order to avoid introducing bias in responses to the open-ended questions, and for control purposes, we asked a general question concerning ethnic groupings: "I perceive myself as:" and listed categories, different for every country, following their census categories. For the US these were: Caucasian, African-American, Hispanic, Asian, mixed, other (and the request to specify what "other" was, was added in all countries). For the UK these were: White, Black/African/Caribbean/Black British, Asian/Asian British, Mixed, other. For Mexico: Blanca, Aperlada, Morena, Negra, other. For Poland: White, African, Asian, Latino, other.

Participants: 273 university students from four countries (the US, the UK, Poland, Mexico) took part in this study. The sample in each country exceeded the 30 persons recommended for qualitative research (Marshall, Cardon, Poddar \& Fontenot, 2013). All participants were citizens of the country where the survey was taken. The samples can be described as follows:

- 45 U.S. students: 75\% female, 18-35 years old, mean age 19.6; 84\% White, 7\% AfricanAmerican, 2\% Asian, 2\% African-American and Hawaiian, 2\% Hispanic, 2\% Middle Eastern; 10\% agnostics or none-believers, 83\% Christians (including 9\% Catholic, 7\% Baptist, 7\% Church of Christ) and 2\% Muslims;

- 48 U.K. students: $66 \%$ female; $18-73$ years old, mean age 34; 64\% White, $19 \%$ Asian/Asian British, 11\% Black/African/Caribbean/Black British, 4\% mixed, 2\% Arab; $32 \%$ agnostics, atheists or none-believers, $36 \%$ of Christians (including $2 \%$ of Roman Catholic and 8\% Church of England), 13\% of Muslims, 9\% of Hindu, and 4\% of others;

- 120 Polish students: $64 \%$ female, 22-58 years old, mean age 28; $100 \%$ White; $7 \%$ agnostics, atheists or non-believers, $93 \%$ of Christians, including Catholics; 
Running head: WHAT IS AN "ETHNIC GROUP" IN ORDINARY PEOPLE'S EYES?

- 60 Mexican students: 47\% female, 17-25 years old, mean age 20; 40\% Aperlada or Morena Clara (light Brown), 36\% Blanca (White), 22\% Morena or Bronce (Brown), 1.7\% Amarilla (Yellow); 20\% agnostics, atheists or none-believers, $80 \%$ of Christians and Catholics.

\section{Coding Procedure:}

Because most participants provided multifaceted definitions of "ethnic group," their answers were partitioned into smaller, semantically different units. Each unit was coded separately as representing a certain category, following the procedure used by Delle Fave et al. (2016). Every answer could have from one to many codes.

The identification of categories was oriented by the research line of "ethnic group" definitions, described in the introduction, and was taken as the reference point to establish a preliminary list of codes. However, the grouping of items within coding categories and subcategories was also data-driven, in line with the third type of the development of concept categories, particularly recommended for more complex answers (Popping, 2015).

The answers were grouped into the following categories, some broader than others: "race"; "nation/country"; "common culture/cultural background," "common customs/traditions," "heritage"; "religion"; "language"; "shared beliefs/values/morals"; "ancestors/family," "genes" and "physical features/looks"; geographical references such as "place of origin," "sharing territory"; "common/shared history" and "common experience"; "similar activities/interests," "common goal," "bond within a group"; "common traits"; "social group," "social class"; "minorities" and "other than me." Some categories may overlap, but we wanted to see the patterns in detail, that is, what categories in the broader category "common culture" are important in certain countries, for example, "religion", "common customs/traditions," "language" etc.

To give an example, here is a quote from a 19-year-old Mexican male student: "It is a group with the same cultural background as language, race, nationality, country or city of origin. You may not know much about the other people in this group, as it could be anyone living in your country or speaking your language, but you can get to have a sense of belonging with 
Running head: WHAT IS AN "ETHNIC GROUP" IN ORDINARY PEOPLE'S EYES?

just having something so small [...] in common."1 This quote was coded as understanding EG as "race," "place of origin," "nation/country," "common culture/traditions" and "language."

For each country, two to four trained raters independently coded each answer unit into a coded item. Discrepancies were discussed until consensus was reached, following the procedure used by Delle Fave and her colleagues (2016).

\section{Results}

We found various understandings of the term "ethnic group" (EG) in the countries studied. The percentage distribution of definitions, grouped into categories, is presented in Table 1.

[Table 1]

Below, we present a detailed analysis of the categories used by participants to define EG, starting from the most popular. As this article aims to give voice to ordinary people and analyze their understanding of the term "ethnic group," we present quotes as examples for all categories and countries. For anonymity, all quotes were described by the age and sex of a participant, for example, 35M means a 35-year-old male. Underscores point out the words from the category which is being described.

\section{1) "Race"}

"Race" was the most common way of defining EG in the US (51\%) and UK (40\%) both in general reference and while giving examples (e.g., US: "White European group," "Hispanic community," "Caucasian," "Blacks and Whites," "African American," "Native Americans," "Arab"; in the UK, "race" was often mixed with "place of origin" or national criteria, e.g., "White British," "White British - English," "Asian British," "black African," "Caucasian," "AfroCaribbean," "black and white Caribbean").

For $7 \%$ of U.S. students, referring to "race" was connected to simultaneously mentioning other EG characteristics, such as religion (e.g. "Ethnic groups are based on race and religious beliefs. I am a white Protestant" 19M²), "ancestors/family" (e.g. "Members of similar descent that share common ancestors. I am in the White European group"19M) or geographical reference (e.g. "Middle Eastern groups on campus"). In the UK, for $6 \%$ of students, referring to

${ }^{1}$ All quotes in the original spelling. The Mexican sample's quotes were translated from Spanish by the 4th author.

2 As explained before, this shortcut describes participants' age and sex, so it this case it was 19year old male respondent. 
Running head: WHAT IS AN "ETHNIC GROUP" IN ORDINARY PEOPLE'S EYES?

"race" was connected to a place of origin (e.g., "An ethnicity is a classification based on race and country of origin, so white-british, black-african, etc." 18M; "an ethnic is a group linked by skin colour or the country they came from or even region." $22 \mathrm{M}$ ) or some other geographical reference $(2 \%)$.

Also, 25\% of Mexicans defined EG as "race" (e.g. "Latinos, Africans, Asians,"

"Caucasian"); however, often in combination with the most popular reference-common culture (see 2), e.g., "A group that comes from the same root in race and culture." (23M); "It is a group of people who identify with a certain race where they can share experiences and traditions. ${ }^{\prime 3}$ (20F).

However, in Poland many other definitions were more popular-only $12 \%$ of participants referred to "race" (e.g. "White," "Black," "African American," "Asians," but also "Roma," "Hind $\left.u^{\prime \prime}\right)$. The most common association in this category was skin color (e.g. "Ethnic group reminds me of a group that is different in color, place of origin, nationality"424F). Interestingly, some respondents seemed to identify "race" with being Slavic. The following two answers are good examples: "Racial origin. I feel Slav." (35M); "association: Slav (white race)" (29F).

\section{2) Direct references to culture and customs: common culture/cultural background,} common customs/traditions, heritage

In Mexico, "common culture/cultural background" ("common culture" for short) was the most popular way of defining EG. Together with "common customs/traditions" it was a reference for over $60 \%$ of Mexicans. The earlier quotes from Mexico are good examples of this definition. Very often "common culture" was combined with other categories_ —.g., "nation" and "shared beliefs/values/morals": "For me, an ethnic group is one who shares customs and culture. Mexicans formed a group that shares the same values" (20F). Some of them also gave examples like "Mayan, Toltec," "Totonac," "indigenous people," "Nahua, Mixtec"; some others listed celebrations, music, art (e.g. "A group of people who share geography, customs, religion, traditions and celebrations " $23 \mathrm{~F}$ ) or style of dress (e.g. see note 24 ).

3 This quote was additionally coded as understanding EG as "common customs/traditions" and "common experience."

${ }^{4}$ All quotes from the Polish sample were translated by the $1^{\text {st }}$ author. This quote was additionally coded as "place of origin," "nation," "other than me."

${ }^{5}$ Additionally coded as "religion," "place of origin." 
Running head: WHAT IS AN "ETHNIC GROUP" IN ORDINARY PEOPLE'S EYES?

Interestingly, for some Mexicans, this category was connected to "ancient" customs with which they do not identify, e.g., "those groups that are still attached or preserve ancient customs as the Maya or so" (17F); "An ethnic group are people with established customs that have not changed, remain the same and do not modernize. They are even groups with their own dialects. ${ }^{\prime 6}(19 \mathrm{M})$.

Referring to common culture was also a very common way of defining EG in Poland (see Table 1), and together with "common customs/traditions" it was a reference used by almost $70 \%$ of Poles (e.g., "A group of people sharing common experiences, culture, and faith. Maintaining the traditions associated with various holidays"7 24F; "An ethnic group for me is a collectivity of people who share a common tradition, culture, religion, and history, most often they inhabit the same territory and use the same language. For me, this is my country, Poland, and Polish citizens. We are bonded by a common language, religion, history and deeply rooted traditions such as, e.g., the customs of Christmas celebrations or the Day of the Dead"8 24F). Some Polish respondents listed cuisine and style of dress (e.g. see note 14).

In the US common culture was the $2^{\text {nd }}$ most popular definition of EG (reference for $22 \%$ of U.S. participants, e.g. "People that have the same culture" 22F), with around 5\% directly referring to "common customs/traditions" ("I understand the concept of an ethnic group as people identifying with each other based on similar social or cultural experience. To me, I would consider people going to the same church or a people celebrating traditions together as ethnic groups $\left.^{\prime \prime 9} 18 \mathrm{~F}\right)$.

Also, about $34 \%$ of Britons gave this answer, and, as with U.S. students, common culture was their second choice. For $11 \%$ of British students, culture and "race" categories were connected (e.g., "Culture specific. White British." $\left.{ }^{10} 41 \mathrm{~F}\right)$. Also, $11 \%$ of them underlined "common customs/traditions" (e.g. "An ethnic group is associated with mutual understandings, traditions (which include dress, food, celebrations)" 29F). Thus, similarly to Polish and Mexican samples, UK students mentioned style of dress and food.

\footnotetext{
${ }^{6}$ Additionally coded as "language."

${ }^{7}$ Additionally coded as "common experience," "religion."

${ }^{8}$ Additionally coded as "common/shared history," "religion," "nation," "sharing territory," "language."

${ }^{9}$ Additionally coded as "common experience," "religion."

${ }^{10}$ Additionally coded as "nation/country."
} 
Running head: WHAT IS AN "ETHNIC GROUP" IN ORDINARY PEOPLE'S EYES?

We spotted referring to cultural heritage among 9\% of British students (e.g. "Ethnic background. The family background they come from that shapes their inalterable characteristics such as their genetics, race, the social culture they were brought up in and their heritage"11 25F; "My thoughts on ethnic group is that it is the heritage of a person. It is a community with its own culture and tradition." 20M) and 4\% of Polish students (e.g., see note 14). It is worth noting that when we add up direct references to culture and customs in the UK, this category seems to be the most popular way of understanding EG in this country, similarly as in Poland or Mexico.

\section{3) Nation/country}

Nationality was another popular category in Poland - almost half of all participants used some connections to "nation/country" as a definition of EG (e.g. "Inhabitants of the certain country" 33F), often directly mentioning the Polish nation as an example of EG (e.g. "Polish people," "Polish nation," "Poles"; "A group of people of the same nationality. This is the Polish nation" 24M).

In the UK, "nation/country" was the third choice, with almost $25 \%$ of Britons referring to it (e.g., "A group of one nationality or colour"12 21F; "I understand an ethnic group to be people from a particular country" $49 \mathrm{~F}$, and other participants giving specific examples such as: "English," "Bangladeshi community," "Bengali," "Asian Guyanese," "Indian, Chinese," "Han Chinese," "Mongolian").

EG was also understood as "nation/country" by $10 \%$ of Mexicans, often connected to "common culture" (e.g., see note 1). Some participants saw the whole country of Mexico as one ethnic group.

This category was somewhat unpopular among U.S. students, as only $7 \%$ referred to it, and it was usually connected to other categories (e.g. "An ethnic group is different races, cultural beliefs, and national experience $\left.{ }^{\prime \prime 13} 18 \mathrm{~F}\right)$.

\section{4) Temporal references: common/shared history, common experience and destiny}

In Poland the "common/shared history" definition was quite popular (third choice among all definitions), with 34\% referring to it. Here is an example of a quite complex answer in this category, simultaneously combined with "common experience" and other categories: "An ethnic

\footnotetext{
${ }^{11}$ Additionally coded as "race," "genes."

${ }^{12}$ Additionally coded as "race."

${ }^{13}$ Additionally coded as "race," "common culture," "common experience," "shared beliefs/values/morals.”
} 
Running head: WHAT IS AN "ETHNIC GROUP" IN ORDINARY PEOPLE'S EYES?

group is a group of people who identify with each other based on common social, cultural, national and historical experiences. Belonging to an ethnic group is usually associated with a common cultural heritage, language, social structure, beliefs, rituals, cuisine, dress, and appearance $^{\prime 14}(23 \mathrm{~F})$.

In the US, UK, and Mexico, this definition was used by less than $10 \%$ of students (e.g. "To understand the concept of an ethnic group you would have to know the history of that group"19M, U.S. student; "I understand this concept by people who identify each other by culture, social and national experience" ${ }^{15}$ 20M, U.K. student), "My ethnic group would be identified as English, having a shared history and culture, and genetic make-up (white)"16 66M, U.K. student).

However, some of the students separately referred to "common experience" as characteristic for EG (7\% in the US and Poland, 4\% in the UK and 3\% in Mexico; e.g., "I understand the concept of an ethnic group as people identifying with each other based on similar social or cultural experience. To me, I would consider people going to the same church or a people celebrating traditions together as ethnic groups. ${ }^{17} 19 \mathrm{M}$, U.S. student) and for some it was a current phenomenon (e.g., see the quote of a Polish student: "These are people with common experiences" $25 \mathrm{~F}$, and note 42 ; for other countries see 11 . and the quotes in notes 7,29 ).

Interestingly, $2 \%$ of Britons mentioned "common destiny" in this context, e.g., "ethnic group is a peculiar group of people with common destiny and belief $f^{\prime \prime 18}(35 \mathrm{M})$.

\section{5) Religion and church}

Religion was used to define "ethnic group" in Poland by almost $30 \%$ of participants (e.g., "Christians," "Catholics," "Muslims," "Jews"; however, most of the participants referred to the Catholic faith, e.g., "Christians (religion) or race"19 20M). Very often "religion/church" was connected to "nation"-14\% of all Polish respondents mentioned them simultaneously (e.g., see note 8$)$.

${ }^{14}$ Additionally coded as "nation/country," "shared beliefs/values/morals," "common culture," "heritage," "common customs/traditions," "physical features/looks," "language."

${ }^{15}$ Additionally coded as "common culture," "nation/country."

${ }^{16}$ Additionally coded as a "race," "nation/country," "genes," "common culture."

${ }^{17}$ Additionally coded as "common culture," "common customs/traditions," "religion/church."

${ }^{18}$ Additionally coded as "shared beliefs/values/morals."

${ }^{19}$ Additionally coded as "race." 
Running head: WHAT IS AN "ETHNIC GROUP" IN ORDINARY PEOPLE'S EYES?

Also, 19\% of Britons pointed out "religion/church" (fourth choice in the matter of popularity, e.g., "colour and religion as well as language. The religion and languages connect me to others and give me a sense of belonging. ${ }^{20} 40 \mathrm{~F}$, others gave specific examples such as "Muslim").

Just $13 \%$ of U.S. students used religion or church to define EG (e.g., "Amish community," "Christians," "Muslims") and was sometimes connected to mentioning "race" (see note 2), and other characteristics (e.g. "An ethnic group is a group of people that share common traits and interests that make up their culture, like religion, language, morals/beliefs, and genes/ancestors" 21 19F; "The concept of an ethnic group is having your own beliefs. I closely associate religion to this. I am a $\underline{\text { Christian }}^{\prime 22} 18 \mathrm{M}$, see also 9.).

This definition was rare among Mexican students (e.g., "Mennonites"; "Jewish community," "Christian") and was often connected to common culture (e.g. "ethnic group is practicing one or another religion and/or culture." 23 19M, also see note 5).

\section{6) Language}

"Language" was another popular reference point for defining "ethnic group," used by $30 \%$ of Polish respondents. Most mentioned the Polish language in this context, making a distinction between Poles and other nations. But there were also examples of special dialects appearing in Poland, such as the Kashubian language, mountaineers dialect, or Silesia dialect; $15 \%$ of Polish respondents simultaneously mentioned nation and language in their answers (e.g. "Ethnicity: it is part of a society or a nation that stands out among this nation, e.g., because of a different language (dialect, patois), Silesians, Basques, Kurds.' 50M).

"Language" was mentioned as an EG characteristic by $14 \%$ of Mexicans (e.g. the Tarahumara language, or more general, e.g., "It is the whole set of people who share physical traits related to a race (in the sociological sense of the word, referring only to physical traits)

${ }^{20}$ Additionally coded as "race," "language."

${ }^{21}$ Additionally coded as "common culture," "shared beliefs/values/morals," "ancestors/family," "genes," "language," "similar activities/interests," "common traits."

${ }^{22}$ Additionally coded as "shared beliefs/values/morals."

${ }^{23}$ Additionally coded as "common culture," "similar activities/interests." 
Running head: WHAT IS AN "ETHNIC GROUP" IN ORDINARY PEOPLE'S EYES?

and a culture, that is, they have a language, dress, customs, traditions, and way of thinking in common. $\left.{ }^{124} 20 \mathrm{~F}\right)$.

The "language" category was very rarely used by students from the UK and US (for examples see notes 20,21).

\section{7) Geographical references: place of origin and shared territory}

This definition was used by almost $20 \%$ of Polish students, mostly as a category "place of origin" or being born in a certain place (usually Poland). Other geographical references, like "sharing territory," were mentioned by $25 \%$ of Polish students (e.g., "Silesians, Basques, Kurds," "Mountaineers," or more general references, e.g. "a group living in the same area, sharing a common culture-a group of Poles" 26M; additionally coded as "common culture"). Interestingly, one person stated that for her ethnic group means "European community."

"Place of origin" or being born in a certain place was mentioned by $11 \%$ of Mexican students (e.g., "being born in particular place"), and "sharing territory"-by $14 \%$ (e.g. "Conglomerate of people living in the same geographical area, which has the same language or dialect and has history, culture, customs, and traditions in common and often has common physical characteristics." 25 25M).

"Place of origin" was also used as a definition of "ethnic group" by British (13\%, see e.g. the quotes mentioned in 1.) and U.S. students (11\%, e.g., "an ethnic group tends to be a group of people based on where they came from, and their race. I'm of the Caucasian American ethnic group" $2635 \mathrm{~F}$ ), but they rarely referred to "sharing territory" as a definition of EG (only $4 \%$ of each sample). For some U.S. students, "place of origin" was also connected to customs and ancestors (e.g., "Ethnic group is a group of people that share the same culture and place of origin. I am from the southern united states so I adhere to the customs associated with this group, along with the western European customs I get from my ancestors." 20M, see also 8.).

Further, some Polish and Mexican students (but not U.K. or U.S.) had very local connotations to EG, mentioning inhabitants of a specific city or other local area (e.g., quotes from two Polish students: "It's a group that shares a common origin, e.g., I come from Warsaw

${ }^{24}$ Additionally coded as "race," "physical features/looks," “common culture," "common customs/traditions," "shared beliefs/values/morals."

${ }^{25}$ Additionally coded as "common culture," "common customs/traditions," "common/shared history," "language," "physical features/looks."

${ }^{26}$ Additionally coded as "race." 
Running head: WHAT IS AN "ETHNIC GROUP" IN ORDINARY PEOPLE'S EYES?

and live in Warsaw. So I identify with people that like me for generations are Varsovians." 27 37F; "According to me, this is a group that has common cultural, historical and national experiences. A community that inhabits a certain territory and identifies with it. My group will be the city of Opole ${ }^{\prime 28} 22 \mathrm{~F}$; and one from a Mexican student: "a group that exists in your city and has the same culture as you. In this I can also put my family and friends that I go to parties with $\left.^{\prime 29} 19 \mathrm{M}\right)$.

\section{8) Ancestors/family, genes and "physical features/looks"}

In the US, "ancestors/family" was the fourth choice, with $13 \%$ of participants referring to it (e.g. "An ethnic group, to me, can be defined as a community/group founded on similar cultural background or descendants" 18M), similar percentage as in the case of religion (see 5.). Referring directly to genes (e.g. "a group of people all coming from the same genetic background" 19F) or "physical features/looks" was much less prevalent.

On the other hand, the "ancestors/family" definition was somewhat unpopular among students from the remaining three countries (see Table 1).

Mexican students mentioned, e.g., "mestizo," "mestizos of America" (which means mixed indigenous and European descent), and also "genes" or "ancestors/family", e.g., "A group of people who share blood traits" 18M; "Race is a set of people who share cultural traits. Specifically, it shares common ancestry that has transmitted not only physical features but also customs, ideas, beliefs, etc. $\left.{ }^{\prime 30} 21 \mathrm{M}\right)$. In this latter example, another code in this category, "physical features/looks," was much more popular in Mexico (14\%) than "genes" or "ancestors/family" (e.g., As a group that shares important physical features, which distinguishes them from other ethnic groups (Caucasian, Saxons)"131 21M; "It is a group of people who share similar physical characteristics and beliefs" $\left.{ }^{\prime 32} 19 \mathrm{M}\right)$.

British students gave similar examples, e.g.: "Ethnic group is a group of people who have a common genealogy and identify with each other because of this" (23F), or "Ethnic

${ }^{27}$ Additionally coded as "place of origin."

${ }^{28}$ Additionally coded as "common culture," "common experience," "common/shared history," "nation/country."

${ }^{29}$ Additionally coded as "common culture," "similar activities/interests," "ancestors/family."

${ }^{30}$ Additionally coded as "race," "common culture," "common customs/traditions," "common traits," "shared beliefs/values/morals."

${ }^{31}$ Additionally coded as "race," "nation/country."

${ }^{32}$ Additionally coded as "shared beliefs/values/morals." 
group-people who share the same culture, the same physical features, potentially same race"33 19F (also see notes 11, 16); as well as Polish (e.g. "ethnic group is a group of people who have similar physical features" $32 \mathrm{M}$; see also note 14 ).

\section{9) Shared beliefs/values/morals}

"Shared beliefs/values/morals" was a definition of "ethnic group" for about $16 \%$ of U.S. students, which makes it the third most popular definition in this sample (e.g. "A group of people you share your beliefs and values with" 19F). Sometimes it was tied directly to "religion" (e.g. "A group of people who have similar morals. I'm associated with Amish communities" 18F).

The "shared beliefs/values/morals" category was similarly popular in the UK and Mexico (see Table 1). Examples include these quotes from a Mexican student: "I understand the concept of ethnic group as a group of people who share the same values, traditions, and customs" (18M; also see the note 32) and from a British student: "Ethnic groups to me are communities of people who are from different cultures or share beliefs ${ }^{\prime 34}(23 \mathrm{~F})$.

In Poland, this category was less popular than ten other definitions, however, it was still used by $9 \%$ of participants (e.g.: "Ethnic group according to me is a group that believes in the same principles, has a common history and culture. In my case it is a group of people identifying themselves as Poles - Slavic nation" ${ }^{\prime 35}$; 23F).

\section{0) "Minus one" understanding: minorities and "different than me"}

As we noted earlier, some people identify ethnic groups only with minorities and/or people different than themselves. It sometimes leads them to a direct declaration of not having ethnicity at all (e.g., a U.S. student said: "ethnic group is a group of people with the same ethnicity, I do not have a specific group" 18F).

Specifically, EG was defined as minorities by over $8 \%$ of Poles and Britons (e.g. "A group who are of minority ethnicity within England" 22F), but by almost no U.S. or Mexican students. The "others" ("different than me") definition appeared among 15\% of Britons (e.g. "For me an ethnic group is a group that is different to me, separated by either colour or religion factors $\left.{ }^{\prime 36} 19 \mathrm{M}\right)$, and $9 \%$ of U.S. students (e.g. "The concept of an ethnic group is a person and/or

${ }^{33}$ Additionally coded as "race", "common culture."

${ }^{34}$ The first of these quotes was additionally coded as "common customs/traditions" and the second-as "common culture."

${ }^{35}$ Additionally coded as "common culture", "common/shared history," "nation/country." ${ }^{36}$ Additionally coded as "religion," "race." 
people whose background differs from that of your own." 18F). It hardly appeared among Poles (e.g. "people of different culture" $13723 \mathrm{~F}$, "my association would be people of different skin color, origin, nationality; I do not feel connected to them $\left.{ }^{\prime 38} 24 \mathrm{~F}\right)$ and Mexicans.

Good examples for understanding EG as both "others" and "minorities" (and denying identification with such ethnic groups) are represented in these quotes from a Mexican student: "An ethnic group refers to a group of people who identify themselves by ethnicity in common, being this Mayan, Toltec, etc. I do not identify with the members of these groups" (21M), and a British student: "I understand an ethnic group to be people from a particular country. People are normally described as ethnic when they are in the minority, either in their country of origin or when they move to another country. I do not identify as ethnic with the above understanding ${ }^{\prime 39}(49 \mathrm{~F})$.

\section{1) Similar activities/interests, common goal and bond within a group}

Some students from the UK, Poland, and Mexico referred to EG as a group with similar activities and interests or hobbies (e.g., being an art, book or karate club member, being runners or people who love traveling together). Good examples are these quotes from Mexican students: "We have the same customs. I strongly identify with the people of my ethnic group, and we have ideas, values, hobbies and similar customs, ${ }^{40} 19 \mathrm{~F}$; "The concept of ethnic group refers to the group of people who come from the same cultural and historical background, develop in the same environment and perform similar activities, $\left.{ }^{\prime 41} 20 \mathrm{M}\right)$; Polish students: "This is a group of people identifying with each other based on shared experience. A group of runners ${ }^{\prime \prime 2}$ (35F), "Ethnic group — people with similar interests, views. This group consists of people with similar beliefs and languages. I am associated, for example, with people who love to travel," $\left.{ }^{43} 23 \mathrm{~F}\right)$; U.S. students: "A common similarity with then a lot of people. That decides to make and join a group. For example would be a book club. My specify group would be Art club, how close did I feel to my member I felt as if I already had something in common with these people" (19F).

${ }^{37}$ Additionally coded as "common culture."

${ }^{38}$ Additionally coded as "race," "place of origin," "nation/country."

${ }^{39}$ Additionally coded as "place of origin," "nation/country."

${ }^{40}$ Additionally coded as "shared beliefs/values/morals," "common customs/traditions."

${ }^{41}$ Additionally coded as "common/shared history," "common culture".

${ }^{42}$ Additionally coded as "common experience."

${ }^{43}$ Additionally coded as "shared beliefs/values/morals" and "language." 
Running head: WHAT IS AN "ETHNIC GROUP" IN ORDINARY PEOPLE'S EYES?

Some students from the UK, Poland, and Mexico also referred to a strong common bond within the group as a characteristic of EG (e.g., a Polish student: "ethnic group, e.g., a cultural or national or a specific group of people focused on a particular field or sport. In my case a karate club and its members; we create such a group in which we feel like a family." ${ }^{44} 25 \mathrm{M}$; a U.S. student: "I think an ethnic group is a group of people that share a very strong common bond." 34F).

Polish and Mexican students (but no British or U.S.) also found a common goal important in defining EG (e.g. "a group of people who are connected with one another in some action. Colleagues I participate in projects with," Polish 35F; "Group pursuing a specific aim," Mexican 20F; "The ethnic groups with people seeking the good of the other group, I identify with the group in my citizenship class since doing projects for social good" Mexican 22F).

\section{2) Common traits}

A few participants described common traits as characteristic of EG, including U.S. students (see note 21), Mexicans (e.g. "Ethnic group is a group of people who share traits and behaviors, which are generally attributed to the fact of belonging to or being born in a particular place. ${ }^{45 "} 20 \mathrm{M}$, or another 20 year old male who mentioned "liking cheerful music" as a trait of Latin Americans), Britons ("the sense of humour associated with England" 19F) and Poles (e.g. "Group, which has its own separate core, distinguishing itself by some traits or connected with each other because of the location. $\left.{ }^{\prime 46} 22 \mathrm{~F}\right)$.

\section{3) Social group, social class}

"Social group" also appeared among EG definitions (e.g. "Ethnic group refers to the different social groups in a community, ranging from the biological to the social, "Mexican19F; "a typical white family with married parents," U.S. 18F; "This may sound strange but for me an ethnic group are parents who every morning bring their 'cats' to small kindergarten... we have the same beliefs; we believe that here the children will turn out good"47 Polish 33F).

For the British and Mexican samples, we also found references to social class or socioeconomic status, e.g., Mexican students wrote: "I consider ethnic group who are close to me and share my socioeconomic status and customs, in my case it would be other students who have

${ }^{44}$ Additionally coded as "common culture," "nation/country."

${ }^{45}$ Additionally coded as "race," "place of origin."

${ }^{46}$ Additionally coded as "sharing territory."

${ }^{47}$ Additionally coded as "shared beliefs/values/morals." 
Running head: WHAT IS AN "ETHNIC GROUP" IN ORDINARY PEOPLE'S EYES?

reasonably affluent families."48 (23F); "A group of people united by having the same race or social status $^{\prime 49}(19 \mathrm{~F})$.

\section{4) Other categories}

Some participants defined ethnic group in terms of having a common "ethnic background" (e.g., see note 11), especially in the UK and the US, usually without explaining what it means to them. A few participants admitted not knowing what ethnic group is or stated: "it is hard to say" ( $2 \%$ in the UK, $1 \%$ in Mexico).

\section{Discussion}

The issue of ethnicity is interdisciplinary, and has been studied by a range of disciplines. The definitions of an "ethnic group" (EG) or of "ethnicity" differ among scholars, across and even within disciplines. Moreover, there is much international confusion in how researchers use the term. Although there is increasing recognition that ethnicity is a complex multidimensional construct, in many cases it continues to be treated as a categorical variable (see e.g. Phinney, 1996). In general, little is known about how ordinary people understand the term when asked for autocategorization in opinion polls or surveys. Our study was conducted to shed light on how ordinary people understand the term "ethnic group" in different countries and cultures. In a crosssectional study U.S., U.K., Mexican, and Polish participants were asked to describe their understandings of the term "ethnic group."

Results indicate that it is often defined as a group with common "race," "culture" and "traditions/customs," "religion," "language" or as "nation/country." However, many other definitions also appeared, with some unexpected, such as a small group of people having the same goal at work, similar activities or hobbies (e.g. travelers, joggers), common social experience (e.g., going to parties together), living in the same city (e.g., Varsovians), as European community, or just family and/or friends.

As expected, we found differences in patterns of EG understanding in the four countries tested, connected with their ethno-cultural context. Over half of U.S. participants understand EG as "race," while half of Polish participants saw it as "nation," and even more than half of Britons, Mexicans and Poles interviewed as broadly understood "culture." "Language" was an important category for $30 \%$ of Polish and 14\% of Mexican participants, while "language" was hardly used

${ }^{48}$ Additionally coded as "common customs/traditions."

${ }^{49}$ Additionally coded as "race." 
Running head: WHAT IS AN "ETHNIC GROUP" IN ORDINARY PEOPLE'S EYES?

in the US and UK. "Physical features/looks" was mentioned by 13\% of Mexicans, while this category rarely appeared in the UK, US or Poland.

To sum up, detailed patterns of understanding "ethnic group" in the four countries tested can be described as follows.

\section{"Ethnic group" definitions in the US}

For the US, as expected, "race" was by far the most dominant way of defining "ethnic group." The most likely reason is that this is a predominant view on ethnicity among U.S. scholars and in national censuses. The separation between European-Americans, AfricanAmericans, Native-Americans, Hispanic-Americans, and Asian-Americans remains strong and salient, also in public discourse. Banton (2015) calls them five pan-ethnic categories. Moreover, in many "multiracial" countries, such as the US, there are profound and persistent "racial" differences in socioeconomic, educational and occupational status, wealth and political power (Smedley \& Smedley, 2005), which makes "race" an important social category in these nations.

"Common culture" was the second most popular EG definition in the US, used by about $27 \%$ of participants and "shared beliefs/values/morals" - by $16 \%$. These results, together with U.S. respondents' low use of "place of origin," "common/shared history" and "common experience" as criteria for EG are likely due to the mixed European ancestry of most EuropeanAmericans (dominant in the U.S. sample). They commonly have ancestors from several European countries, as immigrants from one country commonly married immigrants from another. Thus, it is common for European-Americans to have grandparents from several European countries, making it unlikely that they would use place of origin or shared history and experience to define "ethnic group." The mixed heritage of European-Americans "is now more likely to be passively acknowledged, except for occasional symbolic celebrations. It is no longer an element of everyday ethnicity, subcultural participation or minority status" (Schaefer, 2008, p. 391). It would be interesting to extend the study to the other parts of the country to have a more diverse sample. However, the ancestors category still appeared among more than $13 \%$ of U.S. participants, while in the UK, Poland or Mexico it was less than 10\%.

The fact that only $13 \%$ of U.S. participants referred to religion may be due to religious liberty being a core value in the U.S. Constitution, that Americans are not prone to define ethnic group as different branches of Christianity (e.g., Catholic vs. Protestant). The small numbers of Muslims and followers of other faiths in the US is likely the reason that religion and shared 
Running head: WHAT IS AN "ETHNIC GROUP" IN ORDINARY PEOPLE'S EYES?

beliefs and values were not as salient as "race," and did not come to mind as our participants defined ethnic group. However, anti-Muslim sentiments and the growing number of hate crimes against Muslims (Piter, 2017) might increase the use of the religion category to define EG in the future.

Genetic background or "physical features" were rarely mentioned while defining EG in the U.S. sample. Perhaps U.S. views of ethnicity are influenced by the perspective that ethnicity is a social rather than a biologically determined construct (Smedley \& Smedley, 2005), and hence these biological characteristics may not appear to U.S. respondents as essential aspects of ethnicity.

\section{"Ethnic group" definitions in the UK}

In the UK "ethnic group" was mostly described as "race" (40\%) and "common culture" (over 50\% if we include common customs, traditions and heritage). This "racial" definition of ethnicity may be explained by the fact that "race" is generally described and classified in the British policy documents as "ethnicity" (Evans, 2010), and includes the following categories: White, Black, Asian, Mixed/Multiple and other "more specific categories" which are subsequently broken down into subcategories (Gov.uk, n.d.).

However, the broadly understood category of "culture" was even more popular as an EG understanding, differently than in the US. The explanation of this pattern may be that the UK is a country of cultural and social diversity, in which different cultures follow different customs and traditions, and it may be perceived as a source of ethnic group differentiation.

The UK was the only country in this study where heritage was mentioned by almost $9 \%$ of participants. This idiosyncratic finding can probably be explained by the fact that the UK is the only monarchy in the sample. The Royal Family is an integral part of British culture, with a majority of British citizens supporting this system (Easton, 2012).

Just $20 \%$ or less of British participants mentioned other categories, such as "nation/country," "religion," "shared beliefs/values/morals," or "place of origin." As in the US, reference to "language" rarely appeared, which may be related to the fact that "ethnic groups" are officially defined as "race" in these two countries (Evans, 2010). However, after Brexit, the number of hate crime incidents against "others" (e.g., coming from other EU countries) has risen and the victims' language, place of origin and nation are often listed by perpetrators as "reasons" 
for violence (Ward, 2016). Thus, the importance of these categories as EG criteria might increase in the future.

The remaining categories were used by less than $10 \%$ of Britons, e.g. "common/shared history" (including "common experience" and "common destiny") or biological categories ("genes," "physical features/looks," and "ancestors/family”). The latter is similar to U.S. results on biological characteristics as unimportant for EG definition and may stem from the same belief that ethnicity is a social construction rather than a biologically determined one (Smedley \& Smedley, 2005). Britons also rarely referred to "shared territory" as a definition of EG, which was a bit surprising as it is a sovereign state consisting of four countries, each occupying different parts of the land and Britons often describe their identity in reference to that (McCrone, 2002). Perhaps because the UK is a land separated from other countries by the sea, this description of an "ethnic group" understanding was not an obvious consideration for the participants. Other categories were even less salient in the British sample.

\section{"Ethnic group" definitions in Mexico}

In Mexico, as expected, referring to "common culture" was the dominant way of defining "ethnic group." For Mexicans, customs, traditions, dress, and music, including pre-Hispanic heritage, form an important part of the culture, which is clearly also reflected in the way ethnic groups are understood and defined. Some also mentioned "ancient" customs and traditions as their association with EG, which did not appear in other countries tested. It may be probably interpreted as a result of indigenous groups history still being salient in people's minds in Mexico (e.g. Maya).

"Ethnic group" was defined as "race" by $24 \%$ of the respondents and clearly does not play such an important role in daily discourse as it does in the US or the UK; however, "physical features/looks" was used by $13 \%$ of Mexicans, while hardly used in the other three countries. The Mexican emphases on "physical features/looks" and geographical criteria (especially "shared territory") among definitions of "ethnic group" can be understood as due to the historical territorial isolation of indigenous groups from one another, which resulted in the existence of traditional cultural regions and a striking genetic diversity of ethnic groups (Mexico, n.d.; Moreno-Estrada et al., 2014).

"Language" and "shared beliefs/values/morals" were also mentioned, but by less than $15 \%$ of Mexican participants. It would be interesting to extend the study to the southern and 
central states of Mexico, where the majority of indigenous groups lives. We would expect these categories to be used more, first, because of the daily contact with the community of diverse ethnic groups and awareness of the distinctions between them. And second, because "language" is one of the most important official criteria to distinguish indigenous groups in Mexico (INEGI, 2015a). However, it is also possible that this result is an indication that Mexican scholars may be correct in criticizing national censuses for using a linguistic criterion rather than a socioanthropological one (Sandoval Forero, 2002), as it simply may be not of crucial importance in ordinary people's perspective.

Surprisingly, "religion" was not popular as the definition of "ethnic group" among the Mexican sample, contrary to our expectations, perhaps because the study was conducted in the northern part of the country and religious rituals are more visible in its central and southern parts. It would be interesting to replicate this study on a nationwide sample to include the regions for which religion could be of greater importance.

\section{"Ethnic group" definitions in Poland}

In the case of Poland, we see a clear pattern of defining EG in a way that Haller would call an "ethno-nation": a "nation/country" category, tightly connected to "culture" (underlining traditions like national/religious holidays or referring to cultural heritage), "common/shared history," "language," "religion" and "sharing territory" were commonly used categories to define EG. In addition, $20 \%$ of Poles referred to "place of origin" or being born in a certain placeusually Poland. This pattern reflects Poles' ties with the land and their own nation, strengthened by the historical periods of lost sovereignty and/or independence. It also shows that Poles, as members of a relatively homogeneous society, define "ethnic group" mostly from this historical perspective. Even while having access to other cultural patterns due to travel and media in a globalization era, while being able to see people of different colors, religions or customs, their own country's perspective is the most salient when defining EG.

As expected, defining "ethnic group" by "race" was not popular in Poland (12\%). Of course, it is impossible to say if this result is not just a reflection of views among Polish scholars (see e.g. Rykala, 2014), as radiated through various media. Still, the most common association in this category was skin color, probably because this is the most popular understanding of the term "race" in Poland. Interestingly, some respondents seemed to identify "race" with being Slavic. Again, Poles used their own group as point of reference. 
"Shared beliefs/values/morals" was considered an aspect of the definition of "ethnic group" by just $9 \%$ of Polish students, with almost ten other characteristics of EG mentioned more often. Interestingly, a few Poles referred to similar activities and interests as definitions of "ethnic group" (members of a club, runners, people who love travels, or another shared hobby). Some others referred to inhabitants of favorite cities as examples of EG, perhaps showing their attachment to local communities, confusion about what EG means, or perhaps attempting to override the historical "ethno-nation" discourse with a more modern perspective.

These differences in the patterns of defining the "ethnic group" concept in four different countries appear to confirm Weber's notion that there are no universal traits characterizing ethnic groups. In addition, our results showed that the idea according to which the constructs of "racial" and ethnic identities are largely overlapping (Phinney \& Ong, 2007) or that "race" and ethnicity should be merged into a "race-ethnicity" construct (e.g. Fouad \& Byars-Winston, 2005) would be incorrect for many cultures and nations other than the US and the UK (see also e.g. Helms \& Talleyrand, 1997). We believe that such an approach would distort the picture of the "ethnic group" construct and explain less, not more. The results of our studies conducted in crosscultural context support this conclusion.

However, even for the US, with increasing numbers of mixed ethnicities, such a "raceethnicity" approach may be misleading (Benet-Martinez, 2008). "Many Americans have multiple identities that reflect complex ancestral origins, tribal and communal associations, and varied ideological outlooks on race and culture" (Perez \& Hirschman, 2009, p. 2). Further, people may emphasize different aspects of their ethnicities depending on the situation (Perez \& Hirschman, 2009; Zhang \& Noels, 2013). Such a description of complex, situation dependent ethnic identities also seems accurate for other multiethnic countries studied in this article, such as the UK or Mexico.

The results indicate that the dominant way ordinary people understand EG is connected to official frames provided by national censuses and historical discourse supporting the given perspective: in the US and to some extent also in the UK, it is "race." In Mexico, Poland and the UK, specific culture and common traditions are key. In Poland "nation" and "language" are also important, which are the official criteria to distinguish minorities in this country (MSWIA, n.d.). 
Running head: WHAT IS AN "ETHNIC GROUP" IN ORDINARY PEOPLE'S EYES?

However, there are other categories that ordinary people refer to, not embraced in official national categories such as "culture," appearing in all countries, or country-specific like "physical features/looks" in Mexico (while language, officially used in censuses, is not very popular), heritage in the UK, or "common/shared history" in Poland. Moreover, it seems that participants in all countries tested mostly use their ingroup and the context of their own country as reference points for defining "ethnic group."

The results also indicate that the dominant perspective on "ethnic group" refers to all groups in a society, not to the classic, old "minus one" definition of "ethnic group" as applying to "others" ("different than me") and/or minorities (Banton, 1998). The former was used by 15\% of British and less than $10 \%$ of participants in remaining countries, while the "minorities" category was used by $8 \%$ of British and Polish participants, with hardly any usage in US or Mexico.

\section{Limitations and future studies}

Our research has clear limitations. As most research, especially in cross-cultural context, this study needs to be viewed within its conceptual and methodological boundaries. The study is driven mainly by psychological and sociological work on ethnicity and how individuals understand it. Methodological limitations also include the sampling: samples were comprised of students, although they varied in age and place of residence. Although care was taken to survey comparable groups in the four countries tested, the use of students limits our ability to generalize to the general populations of these countries.

Follow-up studies should include both nationally representative samples and more countries. National samples might add greater variability to the national patterns of defining the term "ethnic group," especially in very diverse countries such as Mexico. However, we feel confident that the main results, showing the key importance of ethno-cultural and national context in the process of defining EG, would almost certainly remain.

In addition, because ethnicity is a social construct that varies across time within any society (Schaefer, 2008), longitudinal research on how individuals change their understanding of EG over time would be useful. Previous analyses showed the importance of a temporal approach to "ethnic group" definitions. The case of the evolving attitudes towards Irish immigrants since they mass immigrated to the UK shows that at the beginning they were portrayed as "Black" and treated as inferior despite their white skin tone (Judd, 1996; Lebow, 1976). Today the word 
"British" refers collectively to all people of Great Britain, whereas in the $17^{\text {th }}$ century it meant only English people, as Irish and Scots were perceived as too different (Schaefer, 2008). Another example may be the changing perspective on ethnicity in the US where "at one point, diversity (...) was cast in biracial, almost caste-like terms as a Black-White issue with American Indians and Asian immigrants virtually ignored" (Schaefer, 2008, p. xlvii), but by the end of the $20^{\text {th }}$ century the discourse changed into talks about the triracial nature of the US or the Latinization of America, while ignoring many other socially defined groups (e.g., Pacific Islanders or tribal groups).

Such longitudinal studies could shed more light on how changes in societal and political context relate to changes in individuals' understanding of the term "ethnic group." For example, it would be important to see how people change their understanding of the concept of ethnic group with increasing numbers of ethnic intermarriages, creating more mixed populations (Schaefer, 2008), how Poles change their definitions of EG as the society becomes more multicultural due to immigration, or how the UK's exit from the EU is related to changes in individuals' descriptions of “ethnic group.” Moreover, given past patterns, and current trends, we cannot be certain that today's group categories will still be valid in the future (Burton et al., 2005; Schaefer, 2008; Zelinsky, 2001), so we believe that studies such as presented in this article will remain useful and should be continued.

\section{Conclusions}

In this cross-sectional and cross-cultural study, we investigated how respondents from four countries (the US, the UK, Poland and Mexico) understand and describe the term "ethnic group." This study provides empirical evidence that individuals from different countries perceive and describe the term in different ways. The summary of national patterns of results seems to make it clear that, in the minds of ordinary people, definitions of the term "ethnic group" are highly culture-dependent, and that most participants use their own country's ethno-cultural and historical context together with official grouping used by national censuses as their basic points of reference. Respondents from the US predominantly connected EG to "race"; British participants perceived EG as also related to "race," but even more to "common culture" and “customs/traditions.” Mexican and Polish respondents also predominantly described EG as related to and expressed in "common culture" and "customs/traditions." However, "nation," "shared history," "religion," "language" and "territory" were also very popular as EG 
understandings in Poland. Unexpected definitions of EG also appeared, e.g., people having similar hobbies, work goals or living in the same city.

In addition, our study showed that most participants used the newer definition of EG (referring to all groups in a society, including minority and majority groups). However, a few in each country used the term only to refer to minorities and people different from themselves (an older, "minus one" definition), which in some cases led to denying having "ethnicity" at all. Further, as our results show, in some cultures (such as in the US, UK or in Mexico), "ethnic group" is more a subgroup within a nation (being a larger context for them), while in others, "ethnic group" and nation are perceived as more closely tied, representing a similar, or even the same, level of categorization, as is the case of Poland.

We believe that our research has shown the importance of taking ethno-cultural, historical and national context as well as ordinary people's understanding of the term into consideration when defining and studying the role of "ethnic group." The results are of theoretical and practical importance. They can contribute to further work on the operationalization of the concept of "ethnic group" or "ethnicity." Researchers could benefit from it when projecting the research and interpreting results of cross-cultural studies. In addition, our results have implications for cross-cultural educational initiatives and for encouraging crosscultural understanding. 
Running head: WHAT IS AN "ETHNIC GROUP" IN ORDINARY PEOPLE'S EYES?

\section{References}

Aboud, F. E., \& Skerry, S. A. (1984). The development of ethnic attitudes. A critical review. Journal of Cross Cultural Psychology, 15, 3-34. doi: 10.1177/0022002184015001001

Banton, M. (1998). Racial theories. Cambridge: Cambridge University Press.

Banton, M. (2007). Max Weber on 'ethnic communities': a critique. Nations and Nationalism, 13(1), 19-35. https://doi.org/10.1111/j.1469-8129.2007.00271.X

Banton, M. (2015). What we now know about race and ethnicity. NY: Berghahn Books.

Barth, F. (Ed.). (1969). Ethnic Groups and Boundaries: The Social Organization of Cultural Difference. Bergen/Oslo: Universitetsforlaget/London: George Allen \& Unwin/Boston: Little, Brown \& Co.

Benet-Martínez, V. (2008). Cross-cultural personality research. In R. W. Robins, C. Fraley, R. F. Krueger (Eds.), Handbook of research methods in personality psychology. NY/London: Gilford Press, 170-189.

Benet-Martinez, V., \& Hong, Y.Y. (Eds.). (2014). The Oxford handbook of multicultural identity. NY: Oxford University Press.

Benet-Martínez, V., \& Oishi, S. (2008). Culture and personality. In LA Clark, D Watson, LA Pervin, OP John (Eds.). Handbook of personality: Theory and research (pp. 542-567). New York, NY, US: Guilford Press.

Bhopal, R., \& Donaldson, L. (1998). White, European, Western, Caucasian, or what? Inappropriate labeling in research on race, ethnicity, and health. American Journal of Public Health, 88, 1303-1307. DOI: 10.2105/AJPH.88.9.1303.

Bobowik, M., Martinovic, B., Basabe, N., Barsties, L., \& Wachter, G. (2017). "Healthy" identities? Revisiting Rejection-Identification and Rejection-Disidentification Models among voluntary and forced immigrants. European Journal of Social Psychology, 47, 818-831. https://doi.org/10.1002/ejsp.2306

Brislin, R.W. (1970). Back-translation for cross-cultural research. Journal of CrossCultural Psychology, 1, 185-216, DOI: 10.1177/135910457000100301

Brubaker, R., Loveman, M., \& Stamatov, P. (2004). Ethnicity as cognition. Theory and Society, 33(1), 31-64. https://doi.org/10.1023/B:RYSO.0000021405.18890.63 
Running head: WHAT IS AN "ETHNIC GROUP" IN ORDINARY PEOPLE'S EYES?

Burton, M.L., Greenberger, E. \& Hayward, C. (2005). Mapping the ethnic landscape: personal beliefs about own group's and other groups' traits. Cross-Cultural Research, 39 (4), 351-379. https://doi.org/10.1177/1069397105274842

Central Statistical Office (2015). Statistical yearbook of the Republic of Poland 2015. Retrieved from http://stat.gov.pl/obszary-tematyczne/roczniki-statystyczne/rocznikistatystyczne/rocznik-statystyczny-rzeczypospolitej-polskiej-2015,2,10.html

Deaux, K., \& Verkuyten, M. (2014). The social psychology of multiculturalism: Identity and intergroup relations. In V. Benet-Martinez, \& Y.Y. Hong (Eds.). The Oxford handbook of multicultural identity (pp. 118-138). Oxford University Press.

Delle Fave, A. et al. (2016). Lay definitions of happiness across nations: The primacy of inner harmony and relational connectedness, Frontiers in Psychology, 7, 1-23. doi: 10.3389/fpsyg.2016.00030

Deniker, J. (1900) Les races et les peuples de la terre: éléments d'anthropologie et d'ethnographie. Paris: Schleicher. 2nd rev. edition, Paris: Masson, 1926.

Duncan, P. \& Edwards, M. (2017, October 10). Huge effect of ethnicity on life chances revealed in official UK figures, The Guardian. Retrieved from https://www.theguardian.com/world/2017/oct/10/huge-effect-of-ethnicity-on-life-chances$\underline{\text { revealed-in-official-uk-figures }}$

Dustmann, C., \& Preston, I. (2001). Attitudes to ethnic minorities, ethnic context and location decisions. The Economic Journal, 111(470), 353-373. https://doi.org/10.1111/1468$\underline{0297.00611}$

Easton, M. (2012, May 29). Why does the UK love the monarchy? BBC. Retrieved from http://www.bbc.co.uk/news/uk-18237280

Ethnic (n.d.-a). In Merriam-Webster Online dictionary. Retrieved from https://www.merriam-webster.com/dictionary/ethnic

Ethnic (n.d.-b). In Oxford Dictionaries. Retrieved from https://en.oxforddictionaries.com/definition/ethnic

Euromonitor International (2016). Mexico: Country profile. Retrieved from Euromonitor Passport database.

Euromonitor International (2017). Population by religion Mexico. Retrieved from Euromonitor Passport database. 
Running head: WHAT IS AN "ETHNIC GROUP" IN ORDINARY PEOPLE'S EYES?

Evans, G. (2010). “What about White People's History?” Class, Race and Culture Wars in Twenty-first-Century Britain. In James, D., Plaice, E. \& Toren, C. (Eds.). Culture Wars: Context, Models and Anthropologists'Accounts (pp. 115-135). Oxford: Berghahn Books Ltd.

EVS (n.d.). European Values Survey, Retrieved from

http://www.europeanvaluesstudy.eu/

Fenton, S. (1999). Ethnicity: Racism, class and culture. Lanham: Rowman \& Littlefield.

Fouad, N. A., \& Byars-Winston, A. M. (2005). Cultural context of career choice: metaanalysis of race/ethnicity differences. The Career Development Quarterly, 53(3), 223-233. doi: 10.1002/j.2161-0045.2005.tb00992.x

García Garza, D. (2013). Aportaciones para el análisis de la cultura empresarial en la universidad mexicana: el caso del Tec de Monterrey. Revista Mexicana De Investigación Educativa, 18, 191-221.

Gilder Lehrman Institute (n.d.). American History: An Introduction. Retrieved from https://www.gilderlehrman.org/history-by-era/immigration-and-migration/essays/history-timesnation-immigrants

Gil-White, F. J. (2005). The study of ethnicity and nationalism needs better categories: Clearing up the confusions that result from blurring analytic and lay concepts. Journal of Bioeconomics, 7(3), 239-270. doi: 10.1007/s10818-005-3007-z

GOV.UK. (n.d.). Ethnicity in the UK. Retrieved from https://www.ethnicity-factsfigures.service.gov.uk/ethnicity-in-the-uk

Haller, M. (2002). Theory and method in the comparative study of values: Critique and alternative to Inglehart. European Sociological Review, 18(2), 139-158.

Hallett, R. (2016, July 20). The world's movement of people - in one map. World Economic Forum. Retrieved from https://www.weforum.org/agenda/2016/07/the-worlds$\underline{\text { immigration-in-one-map/ }}$

Helms, J. E., \& Talleyrand, R. M. (1997). Race is not ethnicity. American Psychologist. 52(11), 1246-1247. http://dx.doi.org/10.1037/0003-066X.52.11.1246

Huynh, Q.-L., Devos, T. \& Altman, H.R. (2015). Boundaries of American identity: Relations between ethnic group prototypicality and policy attitudes. Political Psychology, 36, 449-468. doi:10.1111/pops.12189 
Running head: WHAT IS AN "ETHNIC GROUP" IN ORDINARY PEOPLE'S EYES?

Inglehart, R., \& Welzel, C. (2005). Modernization, cultural change, and democracy: The human development sequence. Cambridge: Cambridge University Press.

Instituto Nacional de Estadística y Geografía (2016). Estadísticas A Propósito Del ...Día Internacional De Los Pueblos Indígenas (9 De Agosto). Retrieved from: http://www.inegi.org.mx/saladeprensa/aproposito/2016/indigenas2016_0.pdf

Instituto Nacional de Estadística y Geografía (2010a). Censo de Población y Vivienda 2010. Cuestionario básico. Retrieved from:

http://www3.inegi.org.mx/sistemas/TabuladosBasicos/Default.aspx?c=27302\&s=est

Instituto Nacional de Estadística y Geografía (2010b). Panorama de las Religiones en México 2010. Retrieved from

http://internet.contenidos.inegi.org.mx/contenidos/Productos/prod_serv/contenidos/espanol/bvine gi/productos/censos/poblacion/2010/panora_religion/religiones_2010.pdf.

Instituto Nacional De Lenguas Indigenas (2008). Catalogo de las Lenguas Indígenas Nacionales: Variantes Lingüísticas de México con sus autodenominaciones y referencias geoestadísticas. Retrieved from http://www.inali.gob.mx/clin-inali/

Isajiw, W. W. (1974). Definitions of ethnicity. Ethnicity, 1(2), 111-124.

Jedlecki, P. (2016, October 20). Ślązacy to też gorszy sort? Nie będą uznani za mniejszość etniczną. Gazeta Wyborcza. Retrieved from http://katowice.wyborcza.pl/katowice/1,35063,20860301,slazacy-to-tez-gorszy-sort-nie-bedauznani-za-mniejszosc-etniczna.html

Judd, J. (1996, March 20). Irish butt of English racism for more than eight centuries, The Independent. Retrieved from https://www.independent.co.uk/news/irish-butt-of-english-racismfor-more-than-eight-centuries-1342976.html

Klimas, B. (2018, June 20). Wschód: samorządy wspierają wielokulturowość. Rzeczpospolita. http://www.rp.pl/Widziane-z-regionu/306209968-Wschod-samorzady-wspieraja$\underline{\text { wielokulturowosc.html }}$

Lebow, R.N. (1976). White Britain and Black Ireland: The influence of stereotypes on colonial policy. Philadelphia: Institute for the Study of Human Issues.

Lee, J., \& Bean, F. (2004). America's changing color lines: Immigration, race/ethnicity and multiracial identification. Annual Review of Sociology, 30, 221-242. https://doi.org/10.1146/annurev.soc.30.012703.110519 
Running head: WHAT IS AN "ETHNIC GROUP" IN ORDINARY PEOPLE'S EYES?

López Beltrán, C. (2000). Para una crítica de la noción de raza. Ciencias 60/61, 98-106. Marshall, B., Cardon, P., Poddar, A. \& Fontenot, R. (2013). Does sample size matter in qualitative research? A review of qualitative interviews in research; Journal of Computer Information, 54, 11-22. http://dx.doi.org/10.1080/08874417.2013.11645667

McCrone, D. (2002) Who do you say you are? Making sense of national identities in modern Britain. Ethnicities, 2(3), 301-320, https://doi.org/10.1177/14687968020020030201

Merino, M.E., \& Tileagă, C. (2011). The construction of ethnic minority identity: A discursive psychological approach to ethnic self-definition in action. Discourse \& Society, 22, 86-101. https://doi.org/10.1177/0957926510382834

Mexico, (n.d.). In Encyclopaedia Britannica online. Retrieved from https://www.britannica.com/place/Mexico/Plant-and-animal-life\#toc27380)

Mexico. Ethnic groups (n.d.). In Encyclopadia Britannica online. Retrieved from https://www.britannica.com/place/Mexico/Ethnic-groups

Milenio (2017). ¿Cuántos indígenas viven actualmente en México? Retrieved from http://www.milenio.com/cultura/cuantos-indigenas-viven-actualmente-en-mexico

Ministerstwo Spraw Wewnętrznych i Administracji (2017). Charakterystyka mniejszości narodowych i etnicznych w Polsce (Characteristics of national and ethnic minorities in Poland). Retrieved from http://mniejszosci.narodowe.mswia.gov.pl/mne/mniejszosci/charakterystykamniejs/6480, Charakterystyka-mniejszosci-narodowych-i-etnicznych-w-Polsce.html

Minkov, M. \& Hofstede, G. (2011). Is national culture a meaningful concept? Cultural values delineate homogeneous national clusters of in-country regions, Cross-Cultural Research, 46(2), p. 133-159. https://doi.org/10.1177/1069397111427262

Moreno-Estrada, A., Gignoux, C.R., Fernández-López, J.C., Zakharia, F., Sikora, M., Contreras, A.V., ... Bustamante, C.D. (2014). The genetics of Mexico recapitulates native American substructure and affects biomedical traits. Science, 344, 1280-1285. http://doi.org/10.1126/science.1251688

Office for National Statistics. (2011). Language in England and Wales: 2011. Retrieved from

https://www.ons.gov.uk/peoplepopulationandcommunity/culturalidentity/language/articles/langu ageinenglandandwales/2013-03-04 
Running head: WHAT IS AN "ETHNIC GROUP" IN ORDINARY PEOPLE'S EYES?

Office for National Statistics. (2012). Ethnicity and National Identity in England and Wales: 2011. Retrieved from

https://www.ons.gov.uk/peoplepopulationandcommunity/culturalidentity/ethnicity/articles/ethnic ityandnationalidentityinenglandandwales/2012-12-11\#ethnicity-in-england-and-wales

Office for National Statistics. (2013). Full story: What does the Census tell us about religion in 2011? Retrieved from https://www.ons.gov.uk/peoplepopulationandcommunity/culturalidentity/religion/articles/fullstor ywhatdoesthecensustellusaboutreligionin2011/2013-05-16

Office for National Statistics. (2017). Migration Statistics Quarterly Report: Feb 2017. Retrieved from https://www.ons.gov.uk/peoplepopulationandcommunity/populationandmigration/internationalm igration/bulletins/migrationstatisticsquarterlyreport/feb2017

Omi, M., \& Winant. H. (1994). Racial Formation in the United States: From the1960s to the 1990s. New York and London: Routledge.

Panagopoulos, C. (2006). The polls-trends: Arab and Muslim Americans and Islam in the aftermath of 9/11. International Journal of Public Opinion Quarterly, 70, 608-624.

https://doi.org/10.1093/poq/nfl029

Perez, A.D., \& Hirschman, C. (2009). The changing racial and ethnic composition of the US population: Emerging American identities. Population and Development Review, 35, 1-51. doi: $\underline{10.1111 / \mathrm{j} .1728-4457.2009 .00260 . \mathrm{x}}$

Persky, I., \& Birman, D. (2005). Ethnic identity in acculturation research. A study of multiple identities of Jewish refugees from the former Soviet Union. Journal of Cross-Cultural Psychology. 36, 557-572. https://doi.org/10.1177/0022022105278542

Peterson, M. F., Søndergaard, M., \& Kara, A. (2017). Traversing cultural boundaries in IB: The complex relationships between explicit country and implicit cultural group boundaries at multiple levels. Journal of International Business Studies, 1-19. https://doi.org/10.1057/s41267017-0082-Z

Pew Research Centre (2015). America's Changing Religious Landscape. Retrieved from http://www.pewforum.org/2015/05/12/americas-changing-religious-landscape/

Pew Research Centre (n.d.). Religious Landscape Study. Retrieved from http://www.pewforum.org/religious-landscape-study/ 
Running head: WHAT IS AN "ETHNIC GROUP" IN ORDINARY PEOPLE'S EYES?

Phinney, J. S. (1996). When we talk about American ethnic groups, what do we mean? American Psychologist, 51(9), 918-927.

Phinney, J.S., Horenczyk, G., Liebkind, K., \& Vedder, P. (2001), Ethnic Identity, immigration, and well-being: An interactional perspective. Journal of Social Issues, 57, 493510. doi:10.1111/0022-4537.00225

Phinney, J. S., \& Ong, A. D. (2007). Conceptualization and measurement of ethnic identity: Current status and future directions. Journal of Counseling Psychology, 54(3), 271-281. DOI: 10.1037/0022-0167.54.3.271

Piter, L. (2017, May 11). Hate crimes against Muslims in US continue to rise in 2016. Human Rights Watch. Retrieved from https://www.hrw.org/news/2017/05/11/hate-crimesagainst-muslims-us-continue-rise-2016

Popping, R. (2015). Analyzing open-ended questions by means of text analysis procedures, Bulletin de Méthodologie Sociologique, 128, 23-39, doi:

$10.1177 / 0759106315597389$

Purkayastha, B. (2008). Ethnic group. In: R.T. Schaefer (ed.) Encyclopedia of Race, Ethnicity, and Society. Thousand Oaks, CA: Sage Publications.

Quraishi, M., \& Philburn, R. (2015). Researching racism: A guidebook for academics and professional investigators. Thousand Oaks, CA: Sage Publications.

Ross, M.H. (1997). The relevance of culture for the study of political psychology and ethnic conflict. Political Psychology, 18, 299-326. doi:10.1111/0162-895X.00059

Rykala, A. (2014). National, ethnic and religious minorities in contemporary Poland. Łódź University Press.

Sandoval Forero, E.A. (2002). Grupos etnolingüísticos en el México del siglo XXI. Papeles de población, 8(34), 219-234.

Schaefer, R.T. (Ed.). (2008). Encyclopedia of Race, Ethnicity, and Society. Thousand Oaks, CA: Sage Publications.

Scotland's Census (2014). Census 2011: Detailed characteristics on ethnicity, identity, language and religion in Scotland - Release 3A. Retrieved from http://www.scotlandscensus.gov.uk/news/census-2011-detailed-characteristics-ethnicity-identitylanguage-and-religion-scotland-\%E2\%80\%93 
Running head: WHAT IS AN "ETHNIC GROUP" IN ORDINARY PEOPLE'S EYES?

Scotland's Census (2011a). Ethnicity. Retrieved from

http://www.scotlandscensus.gov.uk/ods-

visualiser/\#view=ethnicityChart\&selectedWafers $=0 \&$ selectedRows $=0,1,7,12,16,30$

Scotland's Census (2011b). Religion. Retrieved from

http://www.scotlandscensus.gov.uk/ods-

visualiser/\#view=religionChart\&selectedWafers $=0 \&$ selectedColumns $=0,1,2,3,4,5,6 \&$ selectedRo $\underline{\mathrm{ws}}=0,1,7,12,16$

Senior, P. A., \& Bhopal, R. (1994). Ethnicity as a variable in epidemiological research.

British Medical Journal, 309(6950), 327-330. https://doi.org/10.1136/bmj.309.6950.327

Shiraev, E., \& Levy, D. (2004). Cross-cultural psychology. Critical thinking and contemporary applications. Boston: Pearson Education.

Slawson, N. (2017, October 7). People from ethnic minorities still facing major jobs gap in UK, The Guardian, Retrieved from https://www.theguardian.com/world/2017/oct/07/ethnic$\underline{\text { minorities-jobs-gap-bame-degrees }}$

Smedley, A., \& Smedley, B.D. (2005). Race as biology is fiction, racism as a social problem is real: Anthropological and historical perspectives on the social construction of race. American Psychologist, 60, 16. DOI: 10.1037/0003-066X.60.1.16

Smith, M.G. (1982). Ethnicity and ethnic groups in America: the view from Harvard. Ethnic and Racial Studies, 5(1), 1-22. https://doi.org/10.1080/01419870.1982.9993357

Themstrom, S., Orlov, A., \& Handlin, O. (Eds.). (1980). Harvard encyclopedia of American ethnic groups. Cambridge, MA: Belknap.

UNESCO (1952). The race concept: Results of in inquiry. Paris: UNESCO. http://unesdoc.unesco.org/images/0007/000733/073351eo.pdf

U.S. Census Bureau (2016). Population estimates. Retrieved from https://www.census.gov/quickfacts/table/PST045216/00

UK Office for National Statistics. (2011). Population estimates by ethnic group 2002-2009. Newport, South Wales: Office for National Statistics.

Verkuyten, M. (2018). The social psychology of ethnic identity. London: Routledge.

Verkuyten, M., \& de Wolf, A. (2002a). Being, feeling and doing: Discourses and ethnic self-definitions among minority group members. Culture \& Psychology, 8(4), 371-399. https://doi.org/10.1177/1354067X0284001 
Running head: WHAT IS AN "ETHNIC GROUP" IN ORDINARY PEOPLE'S EYES?

Verkuyten, M., \& De Wolf, A. (2002b). Ethnic minority identity and group context: selfdescriptions, acculturation attitudes and group evaluations in an intra-and intergroup situation. European Journal of Social Psychology, 32(6), 781-800. DOI: 10.1002/ejsp.121

Vermeulen, H. F. (2015) Before Boas: The genesis of ethnography and ethnology in the German Enlightenment. Lincoln and London, NE: University of Nebraska Press.

Vermeulen, H., \& Govers, C. (Eds.). (1994). The anthropology of ethnicity: beyond "Ethnic Groups and Boundaries." Amsterdam: Het Spinhuis.

Ward, B. (2016, September 5). Britain's Brexit hate crime problem. Human Rights Watch. Retrieved from https://www.hrw.org/news/2016/09/05/britains-brexit-hate-crimeproblem

Weinstein, B. (2018, June 13). No ethnic group owns Stuyvesant. All New Yorkers do. The New York Times. Retrieved from https://www.nytimes.com/2018/06/13/opinion/de-blasiostuyvesant-school.html

Wodak, R., \& Reisigl, M. (2003). Discourse and Racism. In: D. Schiffrin, D. Tannen \& H.E. Hamilton (eds.). The Handbook of Discourse Analysis (372-397). Oxford: Blackwell Publishing.

World Values Survey (2015). Cultural map. Retrieved from http://www.worldvaluessurvey.org/images/Cultural_map_WVS6_2015.jpg

World Values Survey (n.d.). Retrieved from http://www.worldvaluessurvey.org/wvs.jsp

Zhang, R., \& Noels, K. A. (2013). When ethnic identities vary: Cross-situation and within-situation variation, authenticity, and well-being. Journal of Cross-Cultural Psychology, 44(4), 552-573.

Zelinsky, W. (2001). The enigma of ethnicity: Another American dilemma. Iowa City, IA: University of Iowa Press. 
Running head: WHAT IS AN "ETHNIC GROUP" IN ORDINARY PEOPLE'S EYES?

Table 1. Percentages of specific types of characteristics reported by participants from the studied countries to describe their understanding of the term "ethnic group", and derived categories.

\begin{tabular}{|c|c|c|c|c|c|}
\hline Category & Codes & Poland & US & Mexico & UK \\
\hline 1. Race & race & $12.3 \%$ & $51.0 \%$ & $24.3 \%$ & $40.4 \%$ \\
\hline \multirow{3}{*}{$\begin{array}{l}\text { 2. Direct references to } \\
\text { "culture", customs } \\
\text { and heritage }\end{array}$} & common culture & $47.5 \%$ & $22.2 \%$ & $32.4 \%$ & $34.0 \%$ \\
\hline & common customs/traditions & $19.7 \%$ & $4.4 \%$ & $31.1 \%$ & $10.6 \%$ \\
\hline & heritage & $4.1 \%$ & $0.0 \%$ & $1.4 \%$ & $8.5 \%$ \\
\hline 3. Nation/country & nation/country & $48.4 \%$ & $6.7 \%$ & $9.5 \%$ & $23.4 \%$ \\
\hline \multirow{3}{*}{$\begin{array}{l}\text { 4. Temporal } \\
\text { references }\end{array}$} & common/shared history & $34.4 \%$ & $6.7 \%$ & $6.9 \%$ & $8.5 \%$ \\
\hline & common experience & $9.0 \%$ & $6.7 \%$ & $2.7 \%$ & $4.3 \%$ \\
\hline & common destiny & $0.0 \%$ & $0.0 \%$ & $0.0 \%$ & $2.1 \%$ \\
\hline 5. Religion & religion/church & $29.5 \%$ & $13.3 \%$ & $8.1 \%$ & $19.1 \%$ \\
\hline 6. Language & common language & $30.3 \%$ & $2.2 \%$ & $13.5 \%$ & $2.1 \%$ \\
\hline \multirow{3}{*}{$\begin{array}{l}\text { 7. Geographical } \\
\text { references }\end{array}$} & place of origin/born in.../roots & $19.7 \%$ & $11 \%$ & $10.8 \%$ & $12.8 \%$ \\
\hline & local e.g. city X & $4.9 \%$ & $0.0 \%$ & $2.7 \%$ & $0.0 \%$ \\
\hline & shared territory & $24.6 \%$ & $4.4 \%$ & $13.5 \%$ & $4.3 \%$ \\
\hline \multirow{3}{*}{$\begin{array}{l}\text { 8. Biological } \\
\text { references }\end{array}$} & ancestors/family & $1.6 \%$ & $13.3 \%$ & $6.8 \%$ & $4.3 \%$ \\
\hline & genes & $3.3 \%$ & $4.4 \%$ & $6.8 \%$ & $8.5 \%$ \\
\hline & physical features/looks & $4.9 \%$ & $2.2 \%$ & $13.5 \%$ & $4.3 \%$ \\
\hline $\begin{array}{l}\text { 9. Shared } \\
\text { beliefs/values/morals }\end{array}$ & shared beliefs/values/morals & $9.0 \%$ & $15.6 \%$ & $14.9 \%$ & $14.9 \%$ \\
\hline \multirow{2}{*}{$\begin{array}{l}\text { 10. "Minus one" } \\
\text { understanding }\end{array}$} & "different than me" & $7.4 \%$ & $8.9 \%$ & $6.8 \%$ & $14.9 \%$ \\
\hline & minorities & $8.2 \%$ & $2.2 \%$ & $2.7 \%$ & $8.5 \%$ \\
\hline \multirow{3}{*}{$\begin{array}{l}\text { 11. Interests and } \\
\text { goals }\end{array}$} & similar activities/interests & $8.2 \%$ & $4.4 \%$ & $8.1 \%$ & $0.0 \%$ \\
\hline & common goal & $3.3 \%$ & $0.0 \%$ & $2.7 \%$ & $0.0 \%$ \\
\hline & $\begin{array}{l}\text { strong common bond within the } \\
\text { group }\end{array}$ & $3.3 \%$ & $4.4 \%$ & $2.7 \%$ & $0.0 \%$ \\
\hline 12. Common traits & common traits & $1.6 \%$ & $4.4 \%$ & $2.7 \%$ & $2.1 \%$ \\
\hline \multirow[t]{2}{*}{ 13. Social class } & social group & $1.6 \%$ & $2.2 \%$ & $2.7 \%$ & $0.0 \%$ \\
\hline & social class/socio-economic status & $0.0 \%$ & $0.0 \%$ & $4.1 \%$ & $2.1 \%$ \\
\hline \multirow[t]{2}{*}{ 14. Other categories } & ethnic background & $0.8 \%$ & $15.6 \%$ & $5.4 \%$ & $19.1 \%$ \\
\hline & "hard to say" & $0.0 \%$ & $0.0 \%$ & $1.4 \%$ & $2.1 \%$ \\
\hline
\end{tabular}

